\title{
Article
}

\section{Reconstructing Historical VOC Concentrations in Drinking Water for Epidemiological Studies at a U.S. Military Base: Summary of Results}

\author{
Morris L. Maslia 1,*, Mustafa M. Aral ${ }^{2}$, Perri Z. Ruckart ${ }^{1}$, and Frank J. Bove ${ }^{1}$ \\ 1 Agency for Toxic Substances and Disease Registry, Atlanta, GA 30341, USA; \\ pruckart@cdc.gov (P.Z.R.); fbove@cdc.gov (F.J.B.) \\ 2 Multimedia Environmental Simulations Laboratory, School of Civil and Environmental Engineering, \\ Georgia Institute of Technology, Atlanta, GA 30332, USA; maral@ce.gatech.edu \\ * Correspondence: mmaslia@cdc.gov; Tel.: +1-770-488-3842
}

\begin{abstract}
A U.S. government health agency conducted epidemiological studies to evaluate whether exposures to drinking water contaminated with volatile organic compounds at U.S. Marine Corps Base Camp Lejeune, North Carolina, were associated with increased health risks to children and adults. These health studies required knowledge of contaminant concentrations in drinking waterat monthly intervals - delivered to family housing, barracks, and other facilities within the study area. Because concentration data were limited or unavailable during much of the period of contamination (1950s-1985), the historical reconstruction process was used to quantify estimates of monthly mean contaminant-specific concentrations. This paper integrates many efforts, reports, and papers into a synthesis of the overall approach to, and results from, a drinking-water historical reconstruction study. Results show that at the Tarawa Terrace water treatment plant (WTP) reconstructed (simulated) tetrachloroethylene (PCE) concentrations reached a maximum monthly average value of 183 micrograms per liter $(\mu \mathrm{g} / \mathrm{L})$ compared to a one-time maximum measured value of $215 \mu \mathrm{g} / \mathrm{L}$ and exceeded the U.S. Environmental Protection Agency's current maximum contaminant level (MCL) of $5 \mu \mathrm{g} / \mathrm{L}$ during the period November 1957-February 1987. At the Hadnot Point WTP, reconstructed trichloroethylene (TCE) concentrations reached a maximum monthly average value of $783 \mu \mathrm{g} / \mathrm{L}$ compared to a one-time maximum measured value of $1,400 \mu \mathrm{g} / \mathrm{L}$ during the period August 1953-December 1984. The Hadnot Point WTP also provided contaminated drinking water to the Holcomb Boulevard housing area continuously prior to June 1972, when the Holcomb Boulevard WTP came on line (maximum reconstructed TCE concentration of $32 \mu \mathrm{g} / \mathrm{L}$ ) and intermittently during the period June 1972-February 1985 (maximum reconstructed TCE concentration of $66 \mu \mathrm{g} / \mathrm{L}$ ). Applying the historical reconstruction process to quantify contaminantspecific monthly drinking-water concentrations is advantageous for epidemiological studies when compared to using the classical exposed versus unexposed approach.
\end{abstract}

Keywords: historical reconstruction; modeling; drinking water; water quality; VOC; epidemiological study; health study; Camp Lejeune

\section{Introduction}

The Agency for Toxic Substances and Disease Registry (ATSDR) conducted epidemiological studies to evaluate health risks in children and adults because of exposures to drinking water contaminated with volatile organic compounds (VOCs) at U.S. Marine Corps Base (USMCB) Camp 


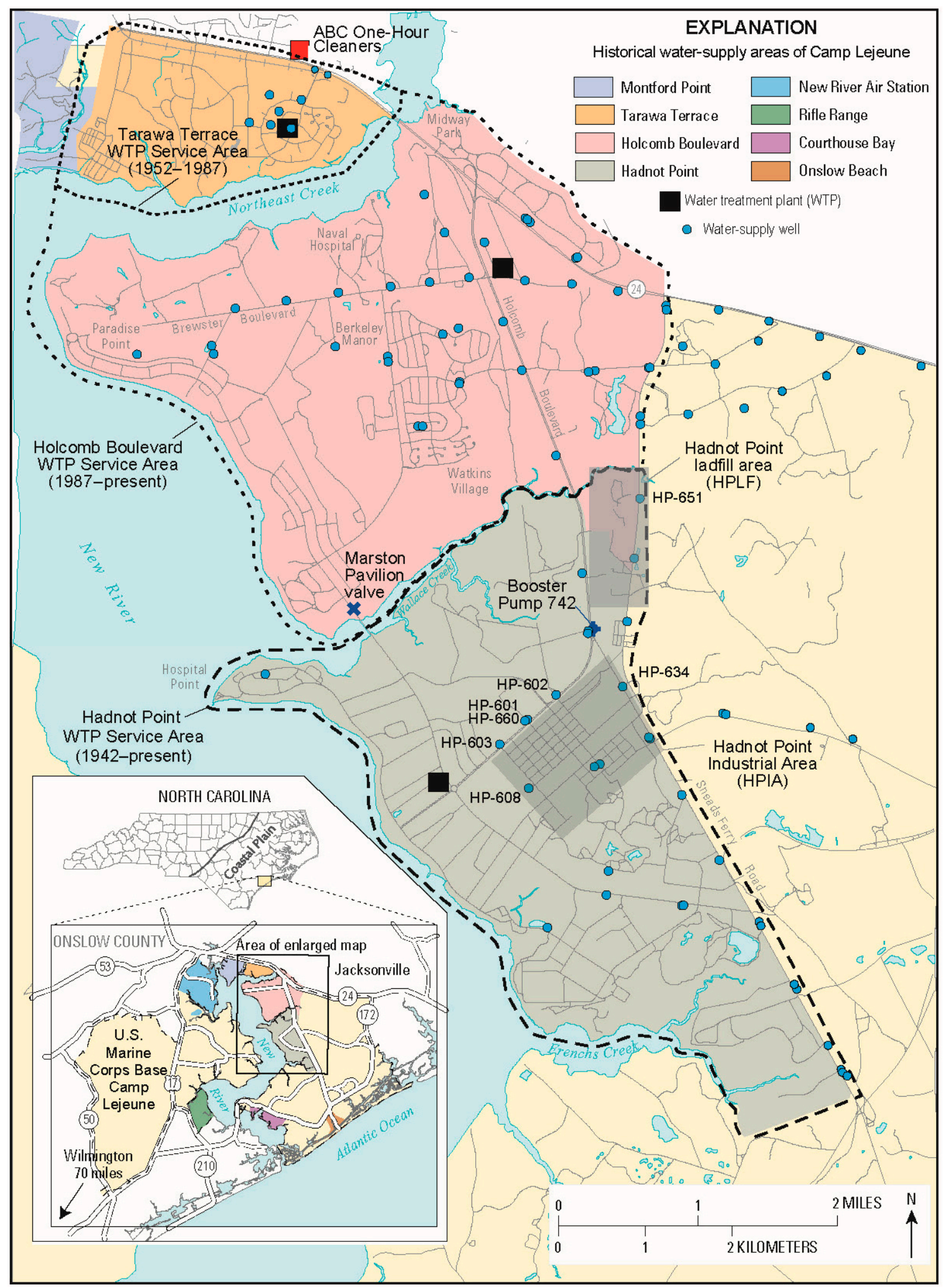

Figure 1. Water-supply areas with focus on housing areas, barracks, and workplaces included in the ATSDR drinking-water exposure and health studies, U.S. Marine Corps Base Camp Lejeune, North Carolina (modified from [1]; $1 \mathrm{mi}=1.61 \mathrm{~km}$ ).

Lejeune, North Carolina (Figure 1). VOCs of interest to the ATSDR studies were tetrachloroethylene (PCE), trichloroethylene (TCE), trans-1,2-dichloroethylene (1,2-tDCE), vinyl chloride (VC), and benzene [1] (Table A3). Measured water-quality data and simulated results are discussed in terms of the U.S. Environmental Protection Agency's (USEPA) maximum contaminant levels (MCLs) for the 
aforementioned VOCs: 100 micrograms per liter $(\mu \mathrm{g} / \mathrm{L})$ for 1,2-tDCE, $5 \mu \mathrm{g} / \mathrm{L}$ for PCE, TCE, and benzene, and $2 \mu \mathrm{g} / \mathrm{L}$ for vinyl chloride. Refer to [2,3] for properties, drinking-water standards, regulations, and MCLs related to VOCs and other chemicals.

Many years of effort have gone into ATSDR's drinking-water exposure and health studies at USMCB Camp Lejeune resulting in numerous agency reports and published papers. Owing to brevity, this paper integrates these efforts, reports, and papers into a synthesis of the overall approach to, and results from, the drinking-water historical reconstruction study. With respect to the three housing areas, barracks, and workplaces of interest to the ATSDR drinking-water exposure and health studies - Tarawa Terrace, Hadnot Point, and Holcomb Boulevard (Figure 1) - Tarawa Terrace results have been previously published [4,5] and will solely be summarized herein. Approaches, methods, and results for the Hadnot Point and Holcomb Boulevard housing areas are presented for the first time herein in the peer-reviewed scientific literature. Specific details for the Tarawa Terrace, Hadnot Point, and Holcomb Boulevard drinking-water analyses are also presented in publicly available ATSDR reports $[1,4]$.

The ATSDR epidemiological studies required estimates or direct knowledge of contaminantspecific concentrations in drinking water - at monthly intervals - delivered to housing, barracks, and workplaces within the study areas. Because of limited or unavailable historical drinking-water concentration data during much of the health-study period (January 1968-December 1985), the historical reconstruction process, which included substantial efforts in information gathering and data mining, water-modeling methods, and sensitivity and probabilistic analyses were used to estimate monthly mean contaminant-specific concentrations. These methods and analyses included linking materials mass balance (mixing) and water-distribution system models to groundwater-flow and contaminant fate and transport models to derive and quantify monthly mean concentrations and ranges of concentrations for contaminants of interest to the ATSDR epidemiological studies (PCE, TCE, 1,2-tDCE, vinyl chloride (VC), and benzene). TCE, VC, and benzene are classified as carcinogenic to humans and PCE is classified as probably carcinogenic to humans [6,7].

\section{Materials and Methods}

\subsection{Background}

USMCB Camp Lejeune is located in the Coastal Plain of North Carolina, in Onslow County, southeast of the City of Jacksonville and about 70 miles $(113 \mathrm{~km})$ northeast of the City of Wilmington, North Carolina. In general, the study area is bounded to the north by North Carolina Highway 24 (SR 24), to the west by New River, to the south by Frenchs Creek, and generally to the east by the drainage divides of upstream tributaries of Wallace and Frenchs Creeks (Figure 1). Northeast Creek separates the Tarawa Terrace base housing area from the Hadnot Point and Holcomb Boulevard base housing areas. Operations began at USMCB Camp Lejeune during late 1941 [8] with the Hadnot Point water treatment plant (WTP) coming on line during 1942 and servicing the entire base until other WTPs were constructed and brought online, such as the Tarawa Terrace WTP during 1952-1953 and the Holcomb Boulevard WTP during June 1972 (Table 1). In 1989, USMCB Camp Lejeune and ABC One-Hour Cleaners (Figure 1) were placed on the USEPA's National Priorities List (NPL) of hazardous waste sites. Table 1 provides a chronological list of selected events related to water supply and environmental contamination at USMCB Camp Lejeune and vicinity.

\subsection{Water Supply and Conctamination}

Groundwater is the sole source of water supply for USMCB Camp Lejeune. Eight waterdistribution systems have supplied or currently (2016) supply drinking water to family housing, barracks, workplaces, and other facilities at USMCB Camp Lejeune. The three water-distribution 
Table 1. Chronology of selected evens related to water supply and environmental contamination at U.S. Marine Corps Base Camp Lejeune, North Carolina, and vicinity. \#,*

\begin{tabular}{ll}
\hline Event & Date or approximate date \\
\hline $\begin{array}{ll}\text { Hadnot Point water treatment plant (WTP) } \\
\text { comes on line }\end{array}$ & $1941-42$ \\
Tarawa Terrace WTP comes on line & $1952-53$ \\
$\begin{array}{l}\text { Holcomb Boulevard WTP comes on line } \\
\begin{array}{l}\text { Several Tarawa Terrace and Hadnot Point } \\
\text { water-supply wells shut down due to } \\
\text { documented volatile organic compound } \\
\text { (VOC) contamination }\end{array}\end{array}$ & June 1972 \\
\hline
\end{tabular}

Marston Pavilion interconnection valve opened and booster pump 742 continuously operated for eight days (because of shut down of Holcomb Boulevard WTP) to augment January 27-February 4, 1985

Holcomb Boulevard drinking-water supply with contaminated Hadnot Point drinking water

Holcomb Boulevard WTP expanded to provide water to Tarawa Terrace and Camp 1987 Johnson water-distribution system areas Tarawa Terrace WTP and remaining operating supply wells shut down and taken March 1987 out of service ABC One-Hour Cleaners placed on the USEPA's National Priorities List (NPL) of contaminated sites USMCB Camp Lejeune placed on the USEPA's NPL of contaminated sites

systems of interest to the ATSDR health studies-Tarawa Terrace, Hadnot Point, and Holcomb Boulevard (Figure 1)-have historically supplied drinking water to the majority of family housing units, enlisted personnel barracks, and workplaces at the base. ATSDR documented information and aggregated data related to water-supply chronology within the study areas of USMCB Camp Lejeune. Details pertinent to water-supply well operations (e.g., construction, in-service, and out-ofservice dates) and WTP operations are provided in $[1,4,9,10]$.

Hadnot Point was the original water-distribution system, serving the entire base with drinking water beginning in the early 1940s. The Hadnot Point WTP was constructed and began operations likely during 1941-1942. The Tarawa Terrace WTP began delivering drinking water during 19521953, and the Holcomb Boulevard WTP began delivering drinking water during June 1972 (Table 1). Currently (2016), the Hadnot Point WTP services the Hadnot Point area, and the Holcomb Boulevard WTP services the Holcomb Boulevard and Tarawa Terrace base housing areas because the Tarawa Terrace WTP was shut down during 1987 due to contamination of several supply wells (Table 1), [4]. 


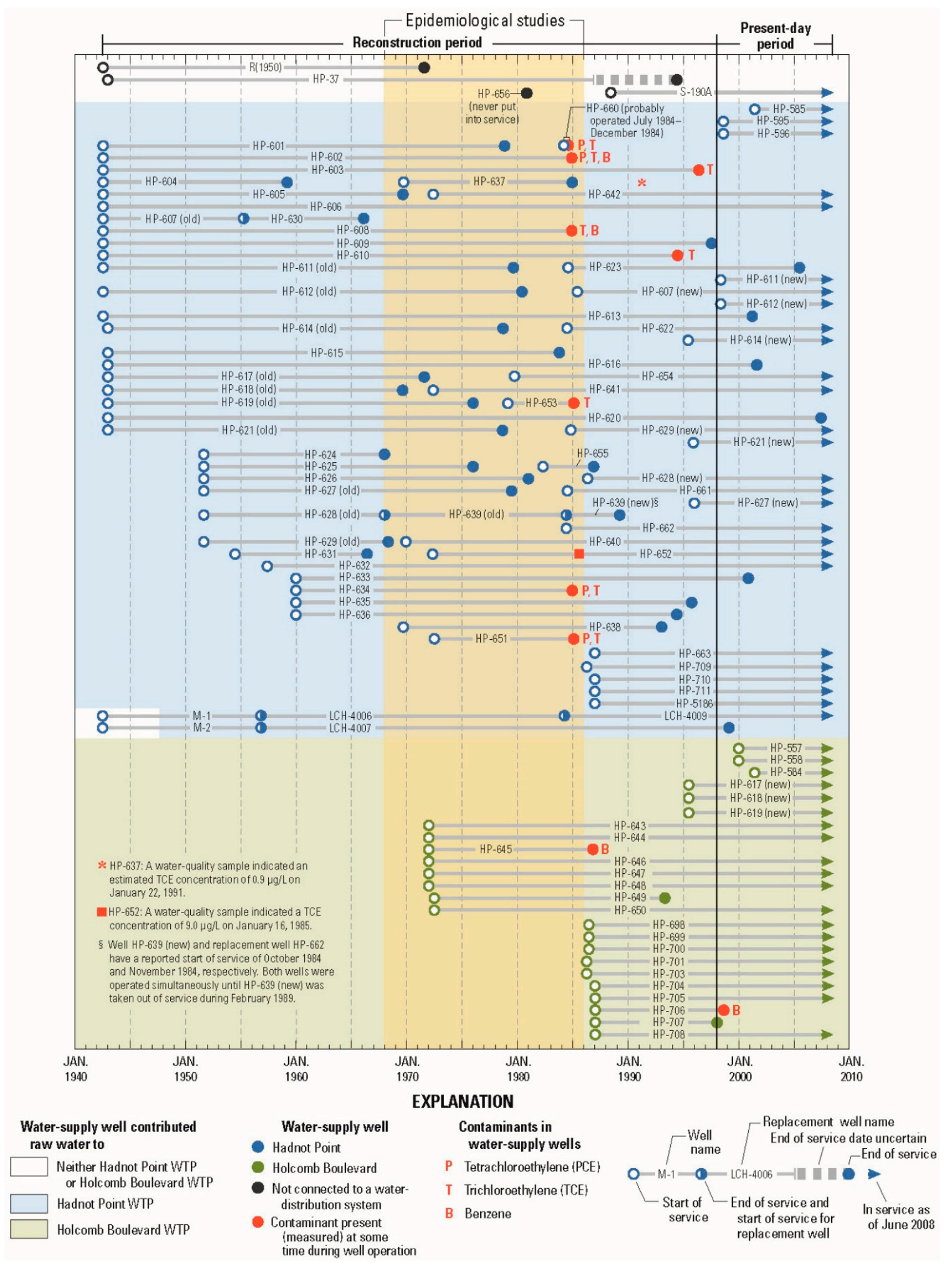

Figure 2. Operational chronologies of Hadnot Point and Holcomb Boulevard water-supply wells, 1942-2008 (from [1]).

The Holcomb Boulevard water-distribution system is connected to the Hadnot Point waterdistribution system at the Marston Pavilion valve and at booster pump 742 (Figure 1). Booster pump 742 was removed during 2007, but the two systems can still be interconnected by opening a valve at the same location. For operational reasons, the two water-distribution systems are rarely connectedexceptions being some documented (and undocumented) intermittent connections that occurred 
during late spring and summer months of 1972-1986 [11] (CLW \#6774-\#8761) and a continuous 8day period of January 28-February 4, 1985 (Table 1), [11] (CLW \#8109, \#8117). Additional discussion of the aforementioned interconnection periods is provided in this paper in the section 3.4 on Intermittent Transfers of Contaminated Drinking Water and in [12]. Operational chronologies for water-supply wells in the Hadnot Point and Holcomb Boulevard study areas during the period 19422008 are shown in Figure 2. This graph shows dates of operation for each well that supplied raw water to the Hadnot Point and Holcomb Boulevard WTPs, the dates when some of the wells were permanently taken out of service, and wells with documented contamination (see [4] for Tarawa Terrace water-supply well operations).

During the early 1980s, high concentrations of VOCs were discovered in groundwater and drinking water serving some areas at USMCB Camp Lejeune. Within the Hadnot Point WTP service area, groundwater was contaminated mostly with TCE, as well as PCE and refined petroleum products, such as benzene, toluene, ethylbenzene, and xylene (BTEX). Historical base operations and lack of environmentally protective disposal practices at USMCB Camp Lejeune have been identified as being responsible for contamination of groundwater and drinking-water supplies within the Hadnot Point WTP service area $[9,13]$. Within the Holcomb Boulevard WTP service area, drinking water remained predominantly uncontaminated except for intermittent supply during spring and summer months by contaminated Hadnot Point water during years 1972-1985. Within the Tarawa Terrace WTP service area, groundwater was contaminated mostly with PCE. An off-base drycleaning facility (ABC One-Hour Dry Cleaners-Figure 1) was identified as being responsible for contaminating several on-base water-supply wells at Tarawa Terrace $[4,5,14]$. Maximum measured concentrations of selected contaminants within the study areas have been documented as follows $[1,4,9]$ :

- $1,400 \mu \mathrm{g} / \mathrm{L}$ of TCE in treated drinking water at the Hadnot Point WTP (May 1982),

- $\quad 380 \mu \mathrm{g} / \mathrm{L}$ and $720 \mu \mathrm{g} / \mathrm{L}$ of benzene in a Hadnot Point WTP supply well (July and December 1984, respectively), and

- $215 \mu \mathrm{g} / \mathrm{L}$ of PCE in treated drinking water at the Tarawa Terrace WTP (February 1985).

ATSDR is required to gather information and data to assess human health impacts from exposures at NPL sites. Because of the potential exposures to high VOC concentrations, ATSDR began health studies in 1995 to evaluate effects of exposure to contaminated drinking water.

\subsection{Historical Reconstruction Methods}

When direct, past knowledge of contaminant concentrations in drinking water is limited or data are unavailable, historical reconstruction methods can be used to provide estimates of contaminant concentrations. Characteristically, historical reconstruction includes information gathering and data mining activities and the application of simulation tools, such as models, to re-create or represent past conditions [1,4,5,15-21]. For ATSDR's drinking-water exposure analyses at USMCB Camp Lejeune, methods included linking materials mass balance (mixing) and water-distribution system models to groundwater-flow and contaminant fate and transport models [1,4,5]. Historical reconstruction results for contaminant-specific concentrations were needed at monthly intervals for the purposes of the epidemiological studies. That is because standard practice in epidemiological studies of adverse reproductive outcomes is an assessment of exposures (whether environmental, occupational, or diet risk factors) at the monthly or trimester level [22] (pp. 602-603). Ideally, these analyses required monthly contaminant concentrations at water-supply wells and at the WTPs. The generalized five-step process used to identify information sources, extract usable model-specific data, and develop, apply, and calibrate models to reconstruct historical contaminant-specific concentrations in drinking water at USMCB Camp Lejeune is shown graphically in Figure 3. The five- 
steps of the process are (1) review information sources, (2) extract information and data and develop databases, (3) develop, simulate, and calibrate models, (4) determine if model conceptualization or calibration issues exist, and if they do, use subject matter experts to iteratively refine model databases and search for additional information sources, and (5) assess when sufficient agreement exists between water-level and contaminant concentration data (historical and present-day) and model results. At that point, historical drinking-water concentration simulation results were extracted from model-output databases and provided to ATSDR epidemiologists for use in the USMCB Camp Lejeune epidemiological analyses [23-27]. By its very nature, historical reconstruction is an iterative process (Figure 3). Contaminant-specific monthly mean concentrations obtained from information sources and data, water-modeling techniques, and the historical reconstruction process were used in the epidemiological studies to estimate the level and duration of exposures to the mother during her pregnancy, to the infant (up to 1 year of age), and to adults (e.g., navy and marine personnel and civilian employees of the Base). It is important to note that throughout the historical reconstruction process, data analysts and water modelers were blinded to the health outcome status of the individuals included in the epidemiological studies.

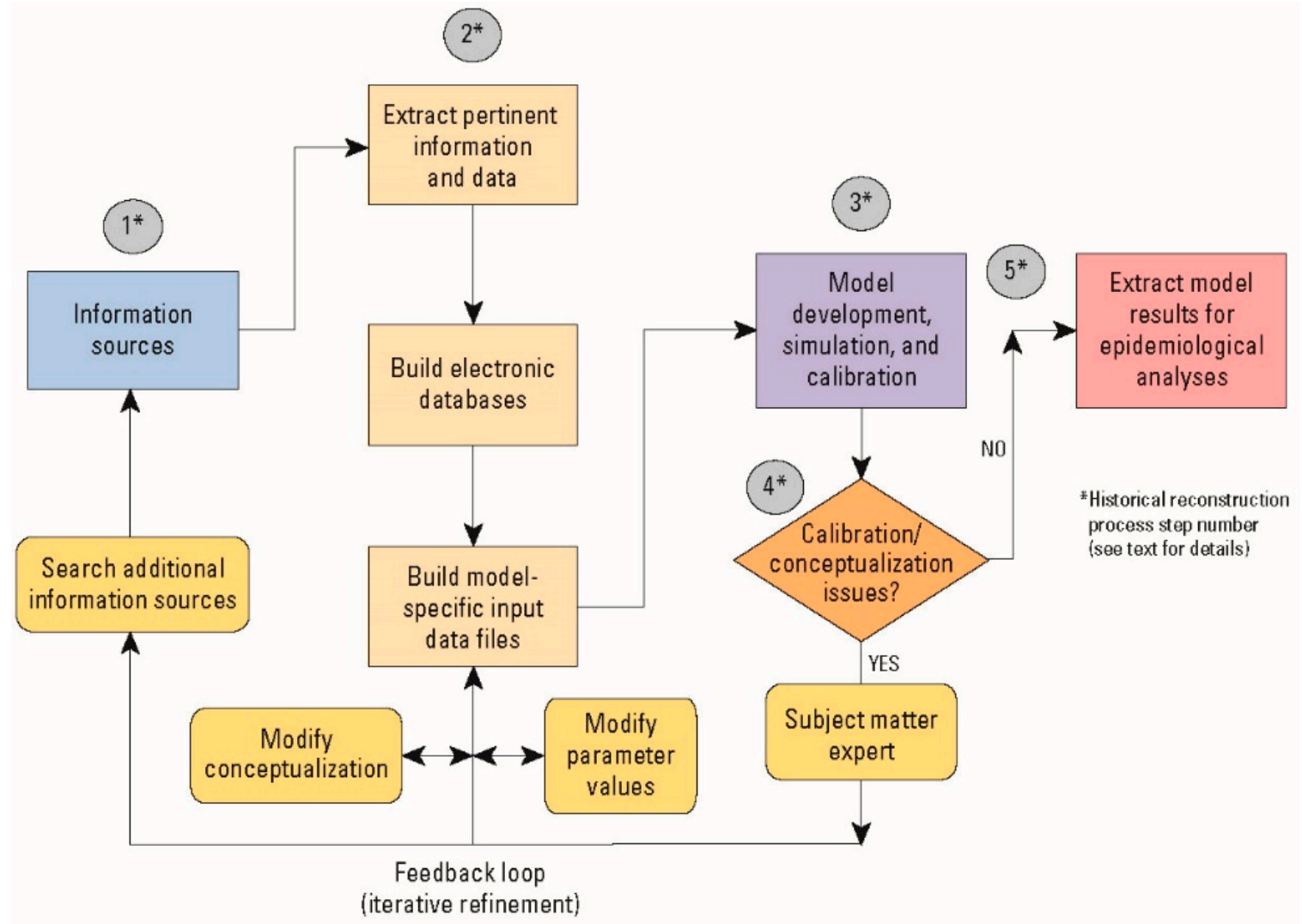

Figure 3. Generalized process of identifying information, extracting usable model-specific data, and applying models to reconstruct historical drinking-water contaminant-specific concentrations (from [1]).

Substantial effort and resources were dedicated to the task of identifying information sources and extracting data because of the voluminous and disparate sources of information and data pertinent to the study area [1] (Appendix A2). The purpose was to obtain information and data that could be extracted and transformed into digital databases in order to conduct historical reconstruction analyses using a modeling approach. By its very nature, information discovery and data mining is not an exact process that can be used or relied upon to identify a single, specific piece of information or data point. Once pertinent model-specific data were identified and extracted, they were entered into digital databases. Model-specific input databases were then developed from these digital databases. 
The analyses and simulation tools used as part of the historical reconstruction process included: (1) geohydrologic analyses, (2) water-distribution system field testing, (3) water-level data to characterize groundwater flow, (4) groundwater-flow and contaminant fate and transport models (for dissolved and light nonaqueous-phase liquid [LNAPL] constituents), (5) parameter sensitivity and uncertainty analyses, (6) probabilistic Markov analyses, and (7) water-distribution system modeling. Brief descriptions of each analysis and simulation tool, the type of analysis (e.g., data, interpretation, or simulation) and supporting references are listed in Table 2. Several novel and innovative methods and models that were developed as part of the historical reconstruction process owing to the very complex character of the study area, the complex historical water-supply well operations (Figure 2), and the need to reconstruct monthly mean contaminant-specific concentrations with reliability. Summarized below are some of these novel and innovative methods (references provided for specific details):

- Effective and efficient (with respect to published methods) fire-flow test method for waterdistribution system model calibration [28],

- Historical monthly operations and pumped groundwater volumes reconstructed for nearly 100 supply wells [29],

- Linear state-space representation of a contaminated aquifer developed to reconstruct historical concentrations in supply wells without the need to use traditional numerical fate and transport modeling [30],

- Volume estimates of lost benzene and LNAPL fate and transport in groundwater [31], and

- Probabilistic Markov process to estimate the number of intermittent transfers of drinking water between a contaminated and uncontaminated drinking-water system [12].

Specific details and descriptions for each type of analysis and each type of model or computational tool are provided in the aforementioned references and in [1].

Table 2. Analyses and simulation tools used to reconstruct historical drinking-water concentrations at U.S. Marine Corps Base Camp Lejeune, North Carolina.

\begin{tabular}{|c|c|c|c|}
\hline Analysis & Description & $\begin{array}{l}\text { Analysis type and } \\
\text { simulation tool }\end{array}$ & Reference \\
\hline $\begin{array}{l}\text { Geohydrologic } \\
\text { framework }\end{array}$ & $\begin{array}{l}\text { Detailed analyses of well and } \\
\text { geohydrologic data used to develop } \\
\text { framework of the Brewster Boulevard } \\
\text { and Castle Hayne aquifer systems } \\
\text { and Tarawa Terrace aquifer }\end{array}$ & $\begin{array}{l}\text { Data analysis and } \\
\text { interpretation }\end{array}$ & [32] \\
\hline $\begin{array}{l}\text { Water-level analyses } \\
\text { and groundwater } \\
\text { flow }\end{array}$ & $\begin{array}{l}\text { Characterizations of water-level data } \\
\text { and groundwater flow }\end{array}$ & $\begin{array}{l}\text { Data analysis and } \\
\text { interpretation }\end{array}$ & [33] \\
\hline $\begin{array}{l}\text { Predevelopment } \\
\text { groundwater flow }\end{array}$ & $\begin{array}{l}\text { Steady-state, three-dimensional } \\
\text { groundwater flow, occurring prior to } \\
\text { initiation of water-supply well } \\
\text { activities (1942) using a grid of } \\
\text { uniform cells of } 300 \mathrm{ft} \text { x } 300 \mathrm{ft}(91 \mathrm{~m} \mathrm{x} \\
91 \mathrm{~m} \text { ) }\end{array}$ & $\begin{array}{l}\text { Simulation using } \\
\text { MODFLOW-2005 }\end{array}$ & {$[34,35]$} \\
\hline
\end{tabular}




\begin{tabular}{|c|c|c|c|}
\hline $\begin{array}{l}\text { Historical water- } \\
\text { supply well } \\
\text { operations }\end{array}$ & $\begin{array}{l}\text { Documenting water-supply well } \\
\text { capacities, histories, and } \\
\text { reconstructing operating schedules } \\
\text { on a monthly basis for the period } \\
\text { 1942-2008 (e.g., Figure 2) }\end{array}$ & $\begin{array}{l}\text { Data analysis, } \\
\text { interpretation, and } \\
\text { simulation using } \\
\text { TechWellOP }\end{array}$ & {$[10,29]$} \\
\hline $\begin{array}{l}\text { Transient } \\
\text { groundwater flow }\end{array}$ & $\begin{array}{l}\text { Unsteady-state, three-dimensional } \\
\text { groundwater flow occurring } \\
\text { primarily because of the initiation } \\
\text { and continued operation of water- } \\
\text { supply wells (July 1942-June 2008), } \\
\text { using a variably-spaced grid ranging } \\
\text { in area from } 300 \mathrm{ft} \times 300 \mathrm{ft}(91 \mathrm{~m} \times 91 \\
\text { m) to } 50 \mathrm{ft} \times 50 \mathrm{ft} \text { ( } 15 \mathrm{~m} \times 15 \mathrm{~m} \text { ) in the } \\
\text { HPIA and HPLF model subdomain } \\
\text { areas }\end{array}$ & $\begin{array}{l}\text { Simulation using } \\
\text { MODFLOW-2005 }\end{array}$ & {$[34,35]$} \\
\hline $\begin{array}{l}\text { Properties of VOCs in } \\
\text { groundwater }\end{array}$ & $\begin{array}{l}\text { Properties of degradation pathways } \\
\text { of common organic compounds in } \\
\text { groundwater }\end{array}$ & Literature survey & [2] \\
\hline $\begin{array}{l}\text { Occurrence of } \\
\text { selected contaminants } \\
\text { in groundwater }\end{array}$ & $\begin{array}{l}\text { Description and summaries of } \\
\text { groundwater contaminants of } \\
\text { selected VOCs and BTEX components } \\
\text { at IRP and AST/UST sites; listing of } \\
\text { water-supply and monitor well } \\
\text { location and construction data }\end{array}$ & Data analysis & {$[9,13]$} \\
\hline $\begin{array}{l}\text { Computation of mass } \\
\text { for PCE, TCE, and } \\
\text { benzene }\end{array}$ & $\begin{array}{l}\text { Estimates of mass (volume) of TCE, } \\
\text { PCE, and benzene in groundwater } \\
\text { using field data and a variety of } \\
\text { analytical and numerical techniques }\end{array}$ & $\begin{array}{l}\text { Site investigation data, } \\
\text { GIS spatial analyses, } \\
\text { LNAPL volume analyses } \\
\text { (TechNAPLVol) }\end{array}$ & {$[9,13,31,36]$} \\
\hline $\begin{array}{l}\text { Fate and transport of } \\
\text { TCE, PCE, and } \\
\text { benzene }\end{array}$ & $\begin{array}{l}\text { Simulation of the fate and migration } \\
\text { of TCE and dissolved benzene from } \\
\text { sources in the HPIA; simulation of } \\
\text { the fate and migration of PCE from } \\
\text { the HPLF; }\end{array}$ & $\begin{array}{l}\text { Simulation using } \\
\text { MT3DMS-5.3 }\end{array}$ & [36-38] \\
\hline $\begin{array}{l}\text { Fate and transport of } \\
\text { benzene (LNAPL) }\end{array}$ & $\begin{array}{l}\text { Simulation of the fate and migration } \\
\text { of benzene as an LNAPL from } \\
\text { sources at the Handot Point fuel farm } \\
\text { in the HPIA; }\end{array}$ & $\begin{array}{l}\text { Simulation using } \\
\text { TechFlowMP }\end{array}$ & {$[31,39-41]$} \\
\hline $\begin{array}{l}\text { Concentrations of } \\
\text { PCE, TCE, 1,2-tDCE, } \\
\text { and VC in a water- } \\
\text { supply well }\end{array}$ & $\begin{array}{l}\text { Reconstructing concentrations of } \\
\text { PCE, TCE, 1,2-tDCE, and VC in } \\
\text { water-supply HP-651 (HPLF)) using a } \\
\text { linear control model methodology }\end{array}$ & $\begin{array}{l}\text { Simulation using } \\
\text { TechControl }\end{array}$ & [30] \\
\hline $\begin{array}{l}\text { TCE, PCE, 1,2-tDCE, } \\
\text { VC, and benzene in } \\
\text { WTP drinking water }\end{array}$ & $\begin{array}{l}\text { Computations of concentrations of } \\
\text { TCE, PCE, 1,2-tDCE, VC, and } \\
\text { benzene in drinking water from the } \\
\text { Hadnot Point WTP using results from } \\
\text { fate and transport and linear control } \\
\text { model simulations }\end{array}$ & $\begin{array}{l}\text { Materials mass balance } \\
\text { model using principles of } \\
\text { conservation of mass and } \\
\text { continuity - algebraic }\end{array}$ & {$[36,42]$} \\
\hline $\begin{array}{l}\text { Parameter uncertainty } \\
\text { and variability }\end{array}$ & $\begin{array}{l}\text { Assessment of parameter sensitivity } \\
\text { and uncertainty associated with } \\
\text { model simulations of groundwater } \\
\text { flow, fate and transport, and water } \\
\text { distribution }\end{array}$ & $\begin{array}{l}\text { One-at-a-time sensitivity } \\
\text { analysis (OAT), Monte } \\
\text { Carl;o (MC) simulation } \\
\text { using Latin hypercube } \\
\text { sampling (LHS), and MC } \\
\text { simulation }\end{array}$ & {$[12,35,36,43]$} \\
\hline
\end{tabular}




\begin{tabular}{llll}
$\begin{array}{l}\text { Intermittent pump } \\
\text { operation for transfer } \\
\text { of drinking water }\end{array}$ & $\begin{array}{l}\text { Probabilistic analysis of the } \\
\text { occurrence of pump operations } \\
\text { during the period 1972-1985 for } \\
\text { transferring Hadnot Point drinking } \\
\text { water to Holcomb Boulevard housing } \\
\text { areas }\end{array}$ & $\begin{array}{l}\text { Probabilistic Markov } \\
\text { analysis using } \\
\text { TechMarkovChain }\end{array}$ & [12,44] \\
$\begin{array}{ll}\text { Distribution of TCE, } \\
\begin{array}{l}\text { PCE, 1,2-tDCE, VC, } \\
\text { and benzene } \\
\text { throughout the }\end{array}\end{array}$ & $\begin{array}{l}\text { Simulation of hydraulics and water- } \\
\text { quality in the water-distribution } \\
\text { system serving the Holcomb } \\
\begin{array}{l}\text { Holcomb Boulevard } \\
\text { housing areas }\end{array}\end{array}$ & $\begin{array}{l}\text { Simulation using } \\
\text { intermittent pump operations } \\
\text { estimated using data and Markov } \\
\text { analysis }\end{array}$ & [12,45] \\
\hline
\end{tabular}

\subsubsection{Modeling of Three-Dimensional Groundwater Flow}

A three-dimensional groundwater-flow model was developed and calibrated based on interpretations of geohydrologic data [32], analyses and interpretations of water-level data, and the conceptual model of groundwater flow for the study area [33]. The groundwater-flow model of the study area consists of 7 layers that were correlated with geologic and hydrogeologic units. Model layers 1, 3, 5, and 7 are correlated with water-bearing units or aquifers, and corresponding model layers 2, 4, and 6 are correlated with semi-confining units or aquitards. Calibrated model parameter values used for simulating groundwater flow and contaminant fate and transport for the Hadnot Point and Holcomb Boulevard study areas are listed in Table 3. Detailed descriptions of deriving the calibrated model input parameter values and calibrated groundwater-flow model input files for use with the MODFLOW model code [34] are provided in [1].

\subsubsection{Modeling of Fate and Transport of Trichloroethylene (TCE) in Groundwater}

Fate and transport simulations of contaminants of concern in groundwater were conducted for PCE, TCE, 1,2-tDCE, VC, and benzene. Owing to the physical and chemical properties of these contaminants and the rigorous analyses of available sampling data, a variety of simulation tools were applied. For example, the simulations of PCE and TCE were conducted as dissolved-phase constituents, whereas the simulation of benzene required volume estimates for floating product, simulation of benzene as a LNAPL, and simulation of benzene as a dissolved constituent in groundwater. Because of space limitations in this paper, groundwater fate and transport simulation details and results are presented solely for TCE. The focus on TCE is chosen because TCE is the primary contaminant in groundwater and drinking water within the Hadnot Point study area and its characteristics in groundwater are similar to those of PCE. Readers desiring complete details on the simulation of the fate and transport in groundwater of other contaminants should refer to the publicly available ATSDR reports [1,31,36]. 
Table 3. Calibrated model parameter values used to simulate groundwater flow and contaminant fate and transport at U.S. Marine Corps Base Camp Lejeune, North Carolina. II

\begin{tabular}{|c|c|c|c|c|c|c|c|}
\hline \multirow{2}{*}{$\begin{array}{l}\text { Model } \\
\text { Parameter }^{+}\end{array}$} & \multicolumn{7}{|c|}{ Model layer number } \\
\hline & 1 & 2 & 3 & 4 & 5 & 6 & 7 \\
\hline \multicolumn{8}{|c|}{ Pre-development (steady-state) groundwater flow model, conditions prior to 1942 - Uniform grid (300 ft x $300 \mathrm{ft}$ cells)§ } \\
\hline $\begin{array}{l}\text { Horizontal hydraulic } \\
\text { conductivity, } K_{x x}(\mathrm{ft} / \mathrm{d})\end{array}$ & $0.5-46.8$ & $1.0-20.0$ & $1.0-50.0$ & $1.0-35.0$ & $2.3-50.0$ & $1.0-20.0$ & 20.0 \\
\hline $\begin{array}{l}\text { Ratio of vertical to } \\
\text { horizontal hydraulic } \\
\text { conductivity, } K_{z z} / K_{x x}\end{array}$ & $1: 10$ & $1: 15$ & $1: 10$ & $1: 15$ & $1: 10$ & $1: 15$ & $1: 10$ \\
\hline $\begin{array}{l}\text { Infiltration (recharge), } I_{i, j} \\
\quad \text { (in./yr) }\end{array}$ & $2.5-22.0$ & - & - & - & - & - & - \\
\hline \multicolumn{8}{|c|}{ Transient groundwater flow model, January 1942-June2008 - Variable-spaced grid $(300 \mathrm{ft} \times 300 \mathrm{ft}-50 \mathrm{ft} \times 50 \mathrm{ft} \text { cells })^{\S}$} \\
\hline Specific yield, $S_{y}$ & 0.05 & - & - & - & - & - & - \\
\hline Specific stoage, $S_{s}^{++}(1 / \mathrm{ft})$ & - & $1.3 \times 10^{-5}-1.9 \times 10^{-4}$ & $4.3 \times 10^{-6}-3.6 \times 10^{-5}$ & $1.0 \times 10^{-5}-3.8 \times 10^{-5}$ & $4.0 \times 10^{-6}-8.3 \times 10^{-6}$ & $1.4 \times 10^{-5}-3.6 \times 10^{-5}$ & $3.4 \times 10^{-6}-7.7 \times 10^{-6}$ \\
\hline $\begin{array}{l}\text { Infiltration (recharge), } I_{i, j} \\
\text { (in./yr) }\end{array}$ & Varies $^{\# \#}$ & - & - & - & - & - & - \\
\hline Pumpage, $\mathrm{Q}\left(\mathrm{ft}^{3} / \mathrm{d}\right) \S \S$ & Varies & Varies & Varies & Varies & Varies & Varies & Varies \\
\hline \multicolumn{8}{|c|}{ Contaminant fate and transport models, January 1942 1951-June2008 - subdomain area $(50 \mathrm{ft} \times 50 \mathrm{ft}$ cells) $\S$} \\
\hline \multicolumn{8}{|l|}{$\begin{array}{l}\text { Distribution } \\
\text { coefficient, } K_{D} \\
\left(\mathrm{ft}^{3} / \mathrm{mg}\right)^{* * *}\end{array}$} \\
\hline PCE & $5.0 \times 10^{-6}$ & $5.0 \times 10^{-6}$ & $5.0 \times 10^{-6}$ & $5.0 \times 10^{-6}$ & $5.0 \times 10^{-6}$ & $5.0 \times 10^{-6}$ & $5.0 \times 10^{-6}$ \\
\hline TCE & $5.3 \times 10^{-9}$ & $5.3 \times 10^{-9}$ & $5.3 \times 10^{-9}$ & $5.3 \times 10^{-9}$ & $5.3 \times 10^{-9}$ & $5.3 \times 10^{-9}$ & $5.3 \times 10^{-9}$ \\
\hline Benzene & $4.0 \times 10^{-9}$ & $4.0 \times 10^{-9}$ & $4.0 \times 10^{-9}$ & $4.0 \times 10^{-9}$ & $4.0 \times 10^{-9}$ & $4.0 \times 10^{-9}$ & $4.0 \times 10^{-9}$ \\
\hline Bulk density, $\rho_{b}\left(\mathrm{~g} / \mathrm{ft}^{3}\right)$ & 47,000 & 47,000 & 47,000 & 47,000 & 47,000 & 47,000 & 47,000 \\
\hline Effective porosity, $n_{E}$ & 0.2 & 0.2 & 0.2 & 0.2 & 0.2 & 0.2 & 0.2 \\
\hline \multicolumn{8}{|l|}{ Biodegradation, $\lambda\left(\mathrm{d}^{-1}\right)$} \\
\hline HPIA (TCE) & $2.0 \times 10^{-3}$ & $2.0 \times 10^{-3}$ & $2.0 \times 10^{-3}$ & $2.0 \times 10^{-3}$ & $2.0 \times 10^{-3}$ & $2.0 \times 10^{-3}$ & $2.0 \times 10^{-3}$ \\
\hline HPIA (benzene) & $1.0 \times 10^{-4}$ & $1.0 \times 10^{-4}$ & $1.0 \times 10^{-4}$ & $1.0 \times 10^{-4}$ & $1.0 \times 10^{-4}$ & $1.0 \times 10^{-4}$ & $1.0 \times 10^{-4}$ \\
\hline $\begin{array}{l}\text { HPLF (PCE and } \\
\text { TCE) }\end{array}$ & $1.4 \times 10^{-4}$ & $1.4 \times 10^{-4}$ & $1.4 \times 10^{-4}$ & $1.4 \times 10^{-4}$ & $1.4 \times 10^{-4}$ & $1.4 \times 10^{-4}$ & $1.4 \times 10^{-4}$ \\
\hline
\end{tabular}




\begin{tabular}{|c|c|c|c|c|c|c|c|c|}
\hline $\begin{array}{l}\text { Effective molecular } \\
\text { diffusion coefficient, } \\
D^{*}\left(\mathrm{ft}^{2} / \mathrm{d}\right)\end{array}$ & $1.0 \times 10^{-3}$ & & $1.0 \times 10^{-3}$ & $1.0 \times 10^{-3}$ & $1.0 \times 10^{-3}$ & $1.0 \times 10^{-3}$ & $1.0 \times 10^{-3}$ & $1.0 \times 10^{-3}$ \\
\hline \multicolumn{9}{|l|}{ Disperssivity (ft) } \\
\hline Longitudinal, $\alpha_{L}$ & 25 & & 25 & 25 & 25 & 25 & 25 & 25 \\
\hline Transverse, $\alpha_{\mathrm{T}}$ & 2.5 & & 2.5 & 2.5 & 2.5 & 2.5 & 2.5 & 2.5 \\
\hline Vertical, $\alpha \mathrm{v}$ & 0.25 & & 0.25 & 0.25 & 0.25 & 0.25 & 0.25 & 0.25 \\
\hline \multicolumn{9}{|c|}{ Source concentration, $C(\mathrm{mg} / \mathrm{L})$} \\
\hline HPIA (TCE) & & 640 & 640 & 640 & 640 & 640 & 640 & 640 \\
\hline HPIA (benzene-dis & ved) & 1.7 & - & - & - & - & - & - \\
\hline HPIA (benzene-LN & & 17 & - & - & - & - & - & - \\
\hline HPLF (PCE) & & $42-105$ & $33-83$ & $27-66$ & $18-46$ & $6-16$ & 0 & 0 \\
\hline HPLF (TCE) & & 256-384 & 256-384 & 256-384 & 256-384 & 256-384 & 256-384 & 256-384 \\
\hline
\end{tabular}

IRefer to [31,35,36] for details;

+Symbolic notation used to describe model parameters obtained from [34,37,38];

"See [1] for correlation between geologic and hydrogeologic units and model layers for the Hadnot Point and Holcomb Boulevard areas; refer to [32,35] for details; aquifers are designated as model layers 1,3,5, and 7; confining units are designated as model layers 2, 4, and 6;

sSee Figure 4 for groundwater-flow model domain and contaminant fate and transport model subdomains;

${ }^{+}$Specific storage $\left(\mathrm{S}_{\mathrm{s}}\right)$ was specified as input for MOFLOW-2005 [34]; based on cell-by-cell thicknesses, specific storage was varied to assure a constant storage coefficient (or

storativity) of $4 \times 10^{-4}$ using the equation $\mathrm{S}=\mathrm{S}_{\mathrm{s}} \times \mathrm{b}$, where $\mathrm{S}$ is the storage coefficient (dimensionles), $\mathrm{S}_{\mathrm{s}}$ is specific storage $(1 / \mathrm{ft})$, and $\mathrm{b}$ is the cell thickness ( $\mathrm{ft}$ );

\#\# Transient infiltration was varied on a monthly basis using the ratio of monthly precipitation divided by average, long-term precipitation; see [35] for details;

\$SPumpage varies by month and model cell; refer to [10,29] for details on the derivation of historical monthly water-supply well operations; refer to [35] for details pertaining to assigning monthly water-supply well pumpage to cells and model layers using the multi-node well-flow package for MODFLOW-2005;

*** Refer to [36] for derivation of $\mathrm{K}_{\mathrm{D}}$ values based on a survey reported in the scientific literature; to convert from model $\mathrm{K}_{\mathrm{D}} \mathrm{units}$ of $\mathrm{ft}^{3} / \mathrm{mg}$ to units of $\mathrm{L} / \mathrm{kg}$ reported in [36], multiply model KD values by 28,381,652.21 


\subsubsection{Modeling of Drinking-Water Concentrations}

Because all water-supply wells were mixed at the Hadnot Point WTP prior to treatment and distribution a materials mass balance (mixing) model, which is based on the principles of continuity and conservation of mass [42], was used compute monthly mean concentrations of TCE in drinking water delivered to base housing and other facilities during the period 1942-1985. Application of the mixing model presumes that the computed concentrations of TCE in drinking water at the WTP are nearly equal to the TCE concentrations of drinking water at any location throughout the WTP service area. This approach was used in $[4,5]$ to reconstruct historical drinking-water concentrations for the Tarawa Terrace study. Applying the mixing model approach to successfully and accurately represent historical water-distribution system contaminant concentrations is documented in [46].

\subsubsection{Modeling of Intermittent Transfers of Contaminated Drinking Water}

During the period June 1972-December 1985, the Hadnot Point and Holcomb Boulevard waterdistribution systems were intermittently interconnected during dry spring and summer months and for an eight-day period of January 28-February 4, 1985. During these periods, contaminated Hadnot Point drinking water was transferred to and distributed within the uncontaminated Holcomb Boulevard water-distribution system. The interconnection of the two water-distribution systems was primarily accomplished by operating booster pump 742, although on rare occasions, the valve at Marston Pavilion (near Wallace Creek) also was opened (Figure 1). Operational records indicating booster pump 742 operations and Marston Pavilion valve openings were only partially documented. Interconnection information and data were obtained from the USMCB Camp Lejeune water utility log books [11] (CLW \#7023-\#8735).

A more complex analysis was necessary (compared to the simple mixing-model approach) to determine the concentration of drinking water in the Holcomb Boulevard water-distribution system during periods of interconnection of the Hadnot Point and Holcomb Boulevard water-distribution systems. This required the application of the EPANET 2 water-distribution system model [45] and extended period simulation (EPS). The EPANET 2 water-distribution system model was calibrated for the Holcomb Boulevard water-distribution system using field data collected by ATSDR; field data represented operational conditions during 2004 [12,28,47,48]. EPSs were used to reconstruct waterdistribution system flow and mass transport patterns during discrete interconnection events when booster pump 742 was intermittently operated, resulting in the transfer of contaminated drinking water from the Hadnot Point water-distribution system to the uncontaminated Holcomb Boulevard water-distribution system. Pipelines represented in the water-distribution system network models are coincident with locations of streets within the Hadnot Point and Holcomb Boulevard area (Figure 1) (e.g., see [46] (Figure I3)). The network representation of the Hadnot Point and Holcomb Boulevard water-distribution systems was simplified by representing the Hadnot Point waterdistribution system as an infinite reservoir on the upstream side of booster pump 742; this allowed for shorter EPANET 2 model runtimes. For the 8-day period, January 28-February 4, 1985, the bypass valve at Marston Pavilion (Figure 1) was documented to have been open, thereby allowing contaminated Hadnot Point drinking water to flow freely through the bypass valve to the Holcomb Boulevard water-distribution system. Because information pertaining to times when interconnection events occurred was limited, and for some years unknown (e.g., 1972-1977), a Markov process [44] was applied using available information to estimate the probability and number of monthly interconnection events that occurred during the months of April-August for years 1972-1985 [1,12]. 


\section{Historical Reconstruction Analyses and Results}

Summaries of results of the historical reconstruction analyses within the Hadnot Point and Holcomb Boulevard areas are discussed and presented in this section of this paper (see $[4,5]$ for historical reconstruction analyses for Tarawa Terrace and vicinity). Results are presented for the following analyses: (1) simulation of three-dimensional groundwater flow, (2) simulations of the fate and transport of TCE within the Hadnot Point Industrial Area (HPIA) and within the Hadnot Point landfill (HPLF) area, (3) computation of monthly mean drinking water concentrations of PCE, TCE, 1,2-tDCE, VC, and benzene at the Hadnot Point WTP, and (4) reconstructed concentrations of TCE within the Holcomb Boulevard housing areas during periods of intermittent water transfers from the Hadnot Point WTP to the Holcomb Boulevard WTP service area during 1972-1985. Complete and detailed descriptions and discussions of historical reconstruction analyses and results are provided in [1].

\subsection{Three-Dimensional Groundwater Flow}

A calibrated predevelopment water-level model-input database was a pre-requisite for conducting transient groundwater-flow and contaminant fate and transport simulationsspecifically in the HPIA and HPLF areas. Predevelopment groundwater flow was conceptualized using approximately 773 water-level measurements, which are listed in [33]. A predevelopment (steady-state) potentiometric surface map of the Brewster Boulevard aquifer system for the study area was developed by using these water-level data along with stream-gage data, climatic data and the geohydrologic framework [1,32]. A potentiometric surface map showing water-level measurements that were used as control points, water-level contours, and the generalized directions of groundwater flow used as the basis for calibrating the predevelopment, three-dimensional groundwater-flow model for the Hadnot Point and Holcomb Boulevard areas is provided in $[1,35]$.

The simulated predevelopment potentiometric contours for the Brewster Boulevard aquifer system, derived from simulated water levels, are shown in Figure 4. The goodness of fit of the predevelopment calibration was assessed by calculating residuals between measured and simulated water levels [35]. Results of the residual analysis are also shown in Figure 4. Within the areas of interest for contaminant fate and transport (the HPIA and HPLF areas) the resulting residuals generally range within $\pm 5 \mathrm{ft}( \pm 1.5 \mathrm{~m})$. For the entire active model domain, nearly 90 percent of the residuals are within a range of $\pm 5 \mathrm{ft}( \pm 1.5 \mathrm{~m})$, which is indicative of an acceptable calibration. Also shown in Figure 4 are simulated directions of groundwater flow, which indicate groundwater originating in the highlands areas and discharging to streams, creeks, and the New River, and flowing through the HPIA and HPLF areas. Comparing the simulated directions of groundwater flow (Figure 4) with the estimated directions of groundwater flow in [1] (Figure A16) indicates general agreement between model results and the conceptual model of groundwater flow for the Hadnot Point and Holcomb Boulevard study area. 


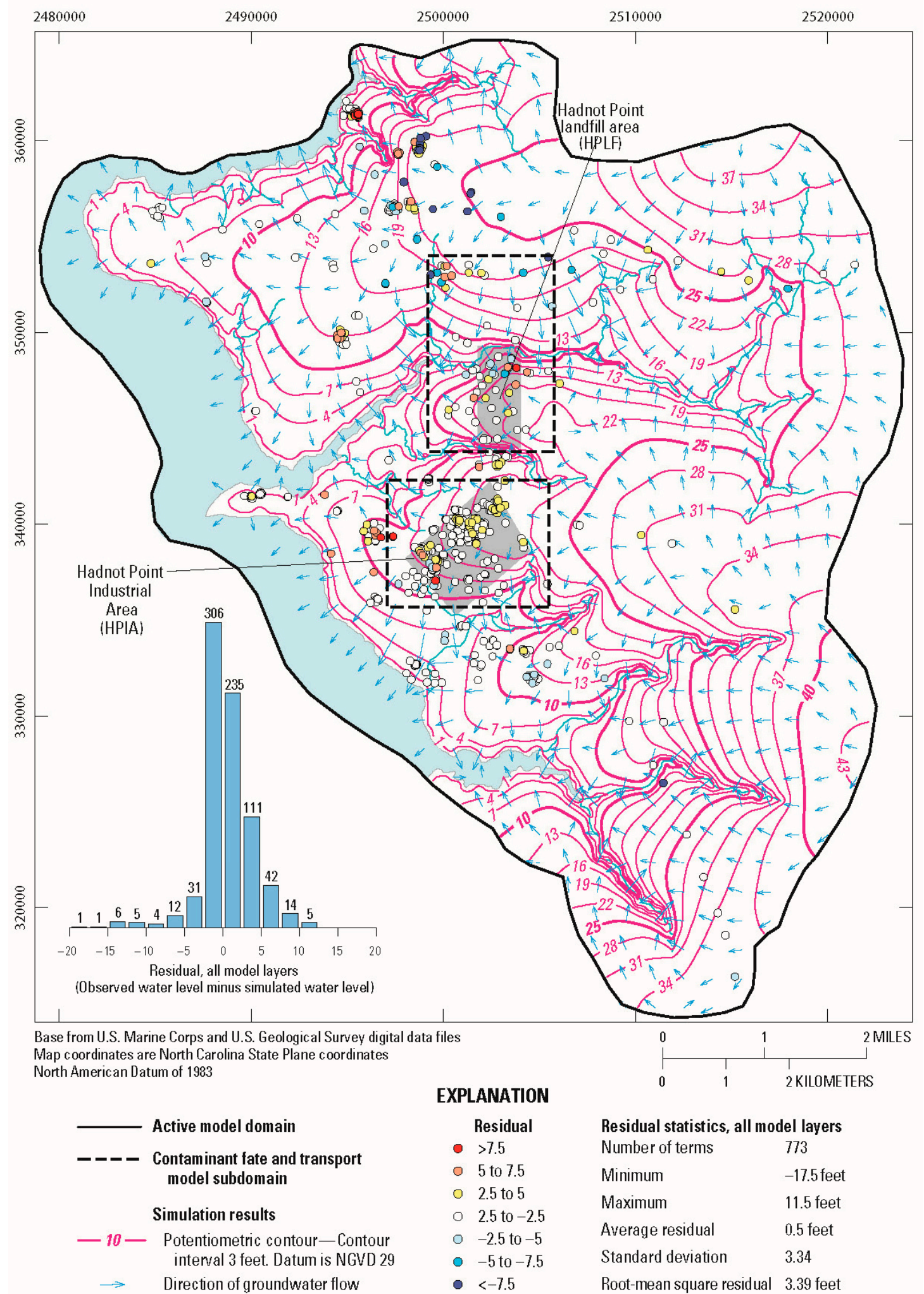

Figure 4. Simulated predevelopment (steady state) potentiometric surface, directions of groundwater flow, and water-level residuals derived from the calibrated three-dimensional groundwater-flow model for the Brewster Boulevard aquifer system at U.S. Marine Corps Base Camp Lejeune, North Carolina (from [1]; $1 \mathrm{ft}=0.3048 \mathrm{~m} ; 1 \mathrm{mi}=1.61 \mathrm{~km}$ ). 


\subsection{Fate and Transport of Trichloroethylene (TCE) in Groundwater}

Four TCE source locations were identified within the HPIA from numerous potential contaminant sources for inclusion in contaminant fate and transport model simulations; two TCE sources were identified within the HPLF area for inclusion in contaminant fate and transport model simulations. The identification, documentation, timelines, locations, and references of contaminant sources are provided in [1] (Table A8). Specific details pertinent to representation of the TCE sources in the contaminant fate and transport model are presented in [36]. Table 4 lists the contaminant sources, locations, concentrations, and durations used for fate and transport simulations within the HPIA and HPLF area. For the HPIA, sources are located near the Building 900 area and near Buildings 1115, 1401, and 1601 (Figure 5a). For historical reconstruction and modeling purposes, it was assumed that TCE sources were introduced to the HPIA during January 1951 (Buildings 1115, 1401, and 1601) and January 1957 (Building 900 area); sources were removed from model simulations during June 1993 (Buildings 1115 and 1601), December 1993 (Building 1401), and December 1994 (Building 900 area). All contaminated water-supply wells were removed from service by December 1985 and were similarly accounted for during model simulations. For the HPLF area, well HP-651 was the primary water-supply well affected by groundwater contamination (Figure 5b). For historical reconstruction and modeling purposes, the two TCE sources were introduced to the HPLF model during January 1948 (Table 4). Well HP-651 began operations during July 1972, was removed from service by February 1985 [10] and was similarly accounted for during model simulations.

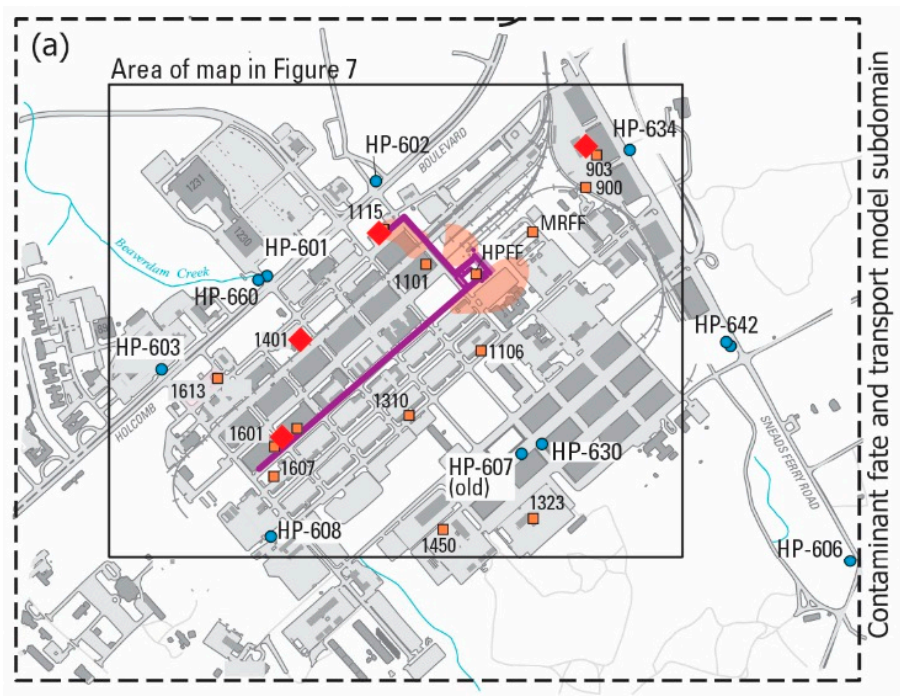

EXPLANATION
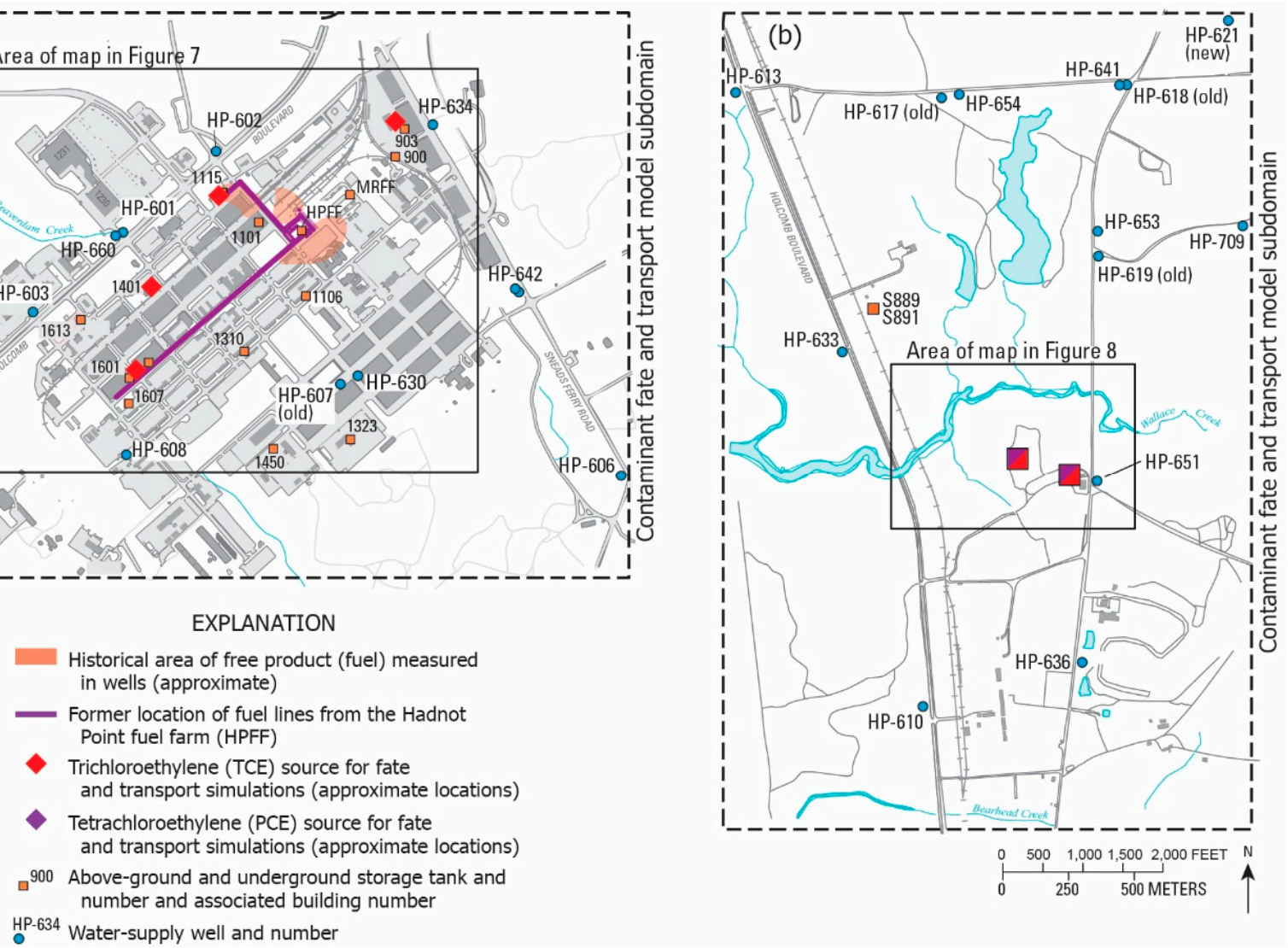

Figure 5. Contaminant fate and transport model subdomain for the: (a) Hadnot Point Industrial Area (HPIA) and (b) Hadnot Point landfill (HPLF) area at U.S. Marine Corps Base Camp Lejeune, North Carolina (modified from [1]; $1 \mathrm{ft}=0.3048 \mathrm{~m}$ ). 
Table 4. Contaminant sources, locations, and durations used for historical reconstruction of TCE, PCE, and benzene concentrations in groundwater at U.S. Marine Corps Base Camp Lejeune, North Carolina ${ }^{\sharp}$.

\begin{tabular}{|c|c|c|c|c|}
\hline Source Location & Contaminant & $\begin{array}{l}\text { Source } \\
\text { concentration } \\
(\mathrm{mg} / \mathrm{L})^{+}\end{array}$ & $\begin{array}{l}\text { Number of } \\
\text { model } \\
\text { sources }^{\S}\end{array}$ & Source duration \\
\hline \multicolumn{5}{|c|}{ Hadnot Point Industrial Area (Figure 5a) } \\
\hline Building 900 area & TCE & 640 & 3 & Jan. 1957-Dec. 1994 \\
\hline Building 1115 & TCE & 640 & 1 & Jan. 1951-Jun. 1993 \\
\hline Building 1401 & TCE & 640 & 1 & Jan. 1951-Dec. 1993 \\
\hline Building 1601 & TCE & 640 & 1 & Jan. 1951-Jun. 1993 \\
\hline Building 1601 & Benzene (dissolved) & 1.7 & 1 & Jan. 1951-Dec. 1994 \\
\hline Building 1613 & Benzene (LNAPL) ${ }^{* *}$ & 17 & Multiple** & Jan. 1964-Jun. 2008 \\
\hline Hadnot Point fuel farm & Benzene (LNAPL)** & 17 & Multiple** & Jan. 1951-Jun. 2008 \\
\hline \multicolumn{5}{|c|}{ Hadnot Point landfill area (Figure 5b) } \\
\hline Source 1++ & TCE & $256-384 \pm$ & 2 & Jan. 1948-Jun. 2008 \\
\hline Source 2++ & PCE & $6-105 \pm$ & 2 & Jan. 1948-Jun. 2008 \\
\hline
\end{tabular}

\#See [1] for complete details.

IIAll model sources are specified concentration; model simulation time is January 1942-June 2008; refer to $[31,36]$ for details.

${ }^{+}$Current maximum contaminant level (MCL) for TCE, PCE, and benzene is $5 \mu \mathrm{g} / \mathrm{L}$; density $\left(20^{\circ} \mathrm{C}\right)$ : TCE, 1.464 $\mathrm{g} / \mathrm{cm}^{3}$; PCE, $1.623 \mathrm{~g} / \mathrm{cm}^{3}$; benzene, $0.876 \mathrm{~g} / \mathrm{cm}^{3}$ [2]; solubility in water $\left(25^{\circ} \mathrm{C}\right): \mathrm{TCE}, 1,280 \mathrm{mg} / \mathrm{L} ; \mathrm{PCE}, 210$ $\mathrm{mg} / \mathrm{L}$; benzene, $1,780 \mathrm{mg} / \mathrm{L}[2]$.

$\S$ Refer to [31,36] for details.

${ }^{* *}$ Benzene source for model is areally distributed based on LNAPL distribution; refer to [31] for details.

${ }^{+}$There are no designated building numbers within the Hadnot Point landfill; location of sources based on Installation Restoration Program Site 82 history and contaminant analyses [9] and model calibration [36]. ${ }^{ \pm}$Source concentration values vary by model layer, refer to [1 (Table A12), 31,36] for details.

Figure 6 shows the reconstructed (simulated) TCE concentrations for water-supply wells HP601/660, HP-602, HP-608, and HP-634 within the HPIA and HP-651 for the HPLF area. Note, watersupply well HP-660 replaced HP-601 and probably operated from July 1984 to December 1984. Monthly reconstructed TCE concentration results occur on the last day of the month (e.g., January 31); they are interpreted as being representative of simulated values on any given day of that month. The results are designated and referred to herein as "monthly mean concentrations of TCE." The reconstructed concentrations at water-supply wells are flow-weighted concentration values for supply wells that are open to multiple water-bearing units $[35,36]$. As can be seen in the graphs of Figure 6, observation data in water-supply wells are very limited and in some instances provide as few as one data point by which to compare reconstructed TCE concentrations (e.g., HP-634). For water-supply wells HP-602 and HP-608, measurements were taken 1 day apart or within a 1-month or less time span, whereas model results represent a mean concentration over an entire month. In the case of HP-651, three of the five water-quality samples were obtained between January 16 and February 4,1985 , and range from 3,200 $\mu \mathrm{g} / \mathrm{L}$ to $18,900 \mu \mathrm{g} / \mathrm{L}$. This makes it difficult to uniquely calibrate a numerical model that at best only approximates the physics, chemistry, and biology of "real-world" conditions and relies on limited observation data, which are subject to measurement error. Given the aforementioned limitations and constraints, the reconstructed (simulated) TCE concentrations provide reasonable agreement with observed data and "real-world" conditions. 

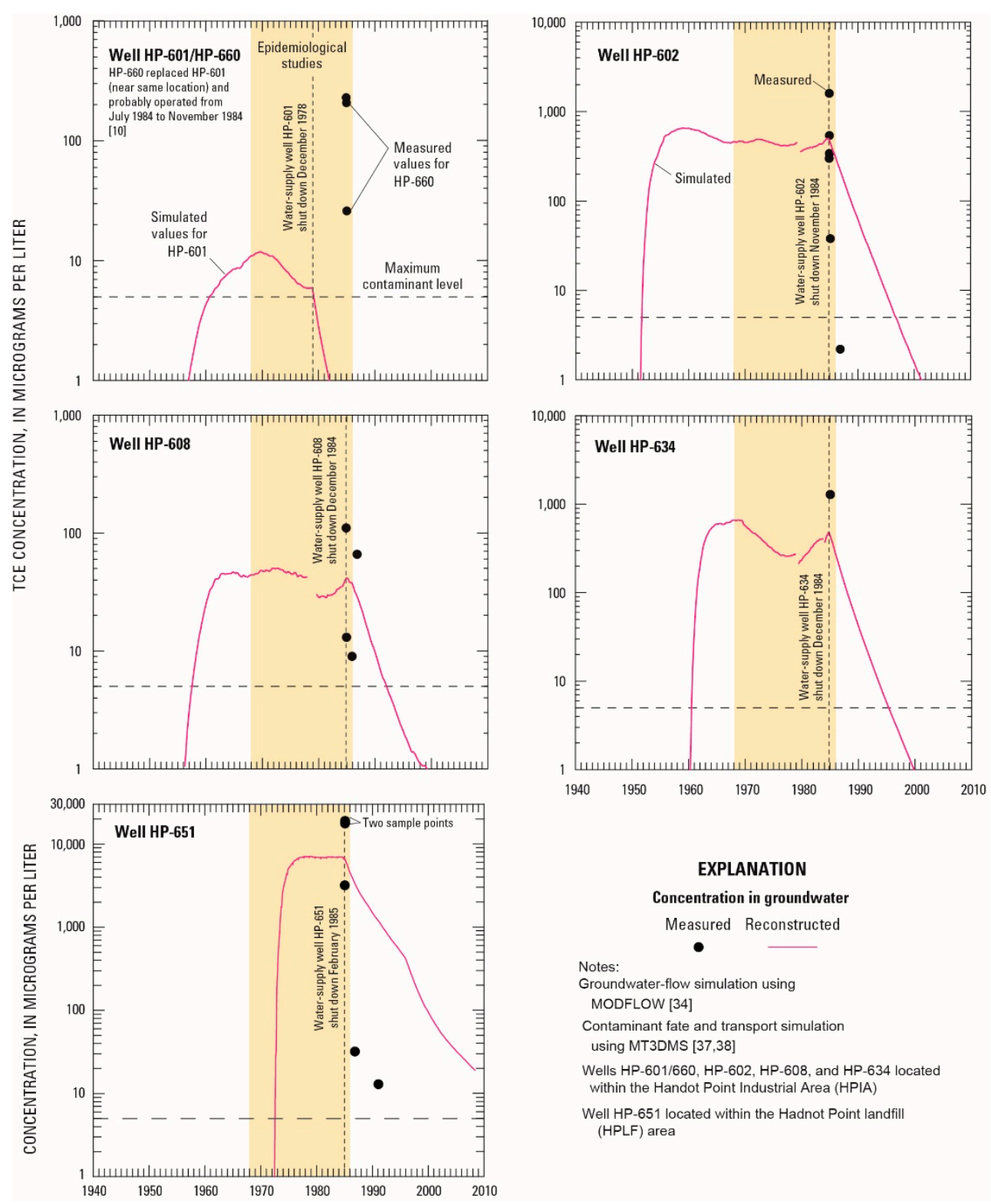

Figure 6. Reconstructed (simulated) and measured concentrations of trichloroethylene (TCE) at selected water-supply wells within the Hadnot Point Industrial Area and the Hadnot Point landfill area at U.S. Marine Corps Base Camp Lejeune, North Carolina (modified from [1]).

Areal distributions of reconstructed TCE concentrations for model layers 1, 3, and 5 within the HPIA for four periods-January 1951, January 1968, November 1984, and June 2008-are shown in Figure 7. Model layers 1, 3, and 5 represent major water-bearing units in the study area and are correlated with the Brewster Boulevard aquifer system, the Tarawa Terrace aquifer, and the Upper Castle Hayne aquifer, respectively [1] (Table A11). Water-supply wells in the study area were open to water-bearing units corresponding to model layers 3 and 5 . The specific simulation dates noted above were selected to show typical historical reconstruction results because (1) January 1951 represents an early time period after the onset of pumping, (2) January 1968 represents the start of the core period for the epidemiological studies, (3) November 1984 represents the month prior to the shutdown of many of the contaminated water-supply wells, and (4) June 2008 represents the end of the historical reconstruction simulation and a time when all contaminated water-supply wells had been removed from service for more than 20 years. Viewed synoptically, the maps in Figure 7 illustrate a progression in the areal distribution of TCE by model layer at the HPIA from the early onset of pumping (January 1951) to substantial impact of TCE on water-supply wells (January 1968 

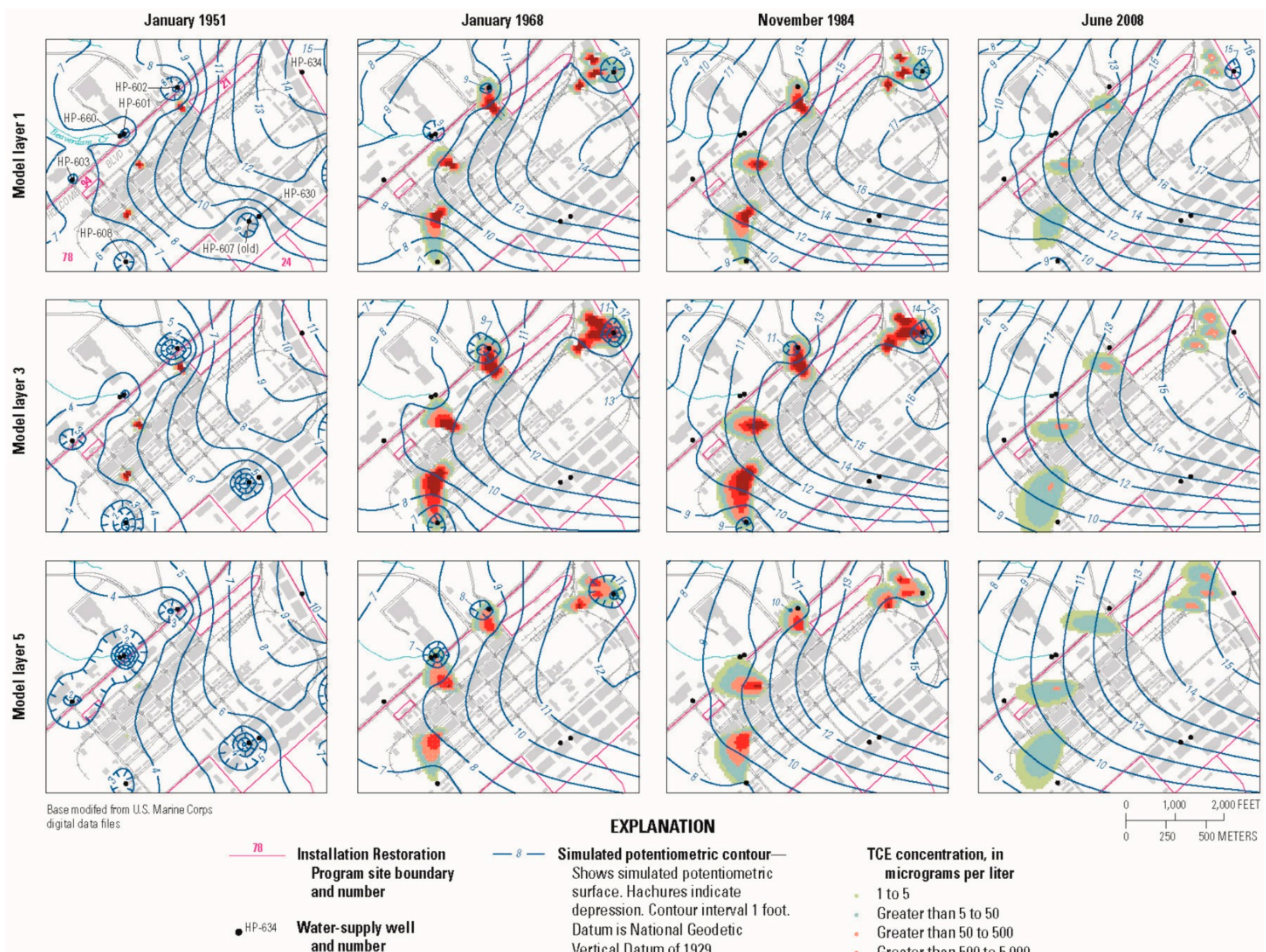
$-8-$ Simulated potentiometric contour- Shows simulated potentiom depression. Contour interval 1 Datum is National Geodetic

EXPLANATION

TCE concentration, in micrograms per liter

1 to 5

Greater than 5 to 50

Greater than 500 to 5,000

Greater than 5.000 to 1.000 .000

Figure 7. Reconstructed (simulated) water levels and distribution of trichloroethylene (TCE) within the Hadnot Point Industrial Area fate and transport model subdomain, model layers 1, 3, and 5, U. S. Marine Corps Base Camp Lejeune, North Carolina (from [1]; $1 \mathrm{ft}=0.3048 \mathrm{~m}$ ). 

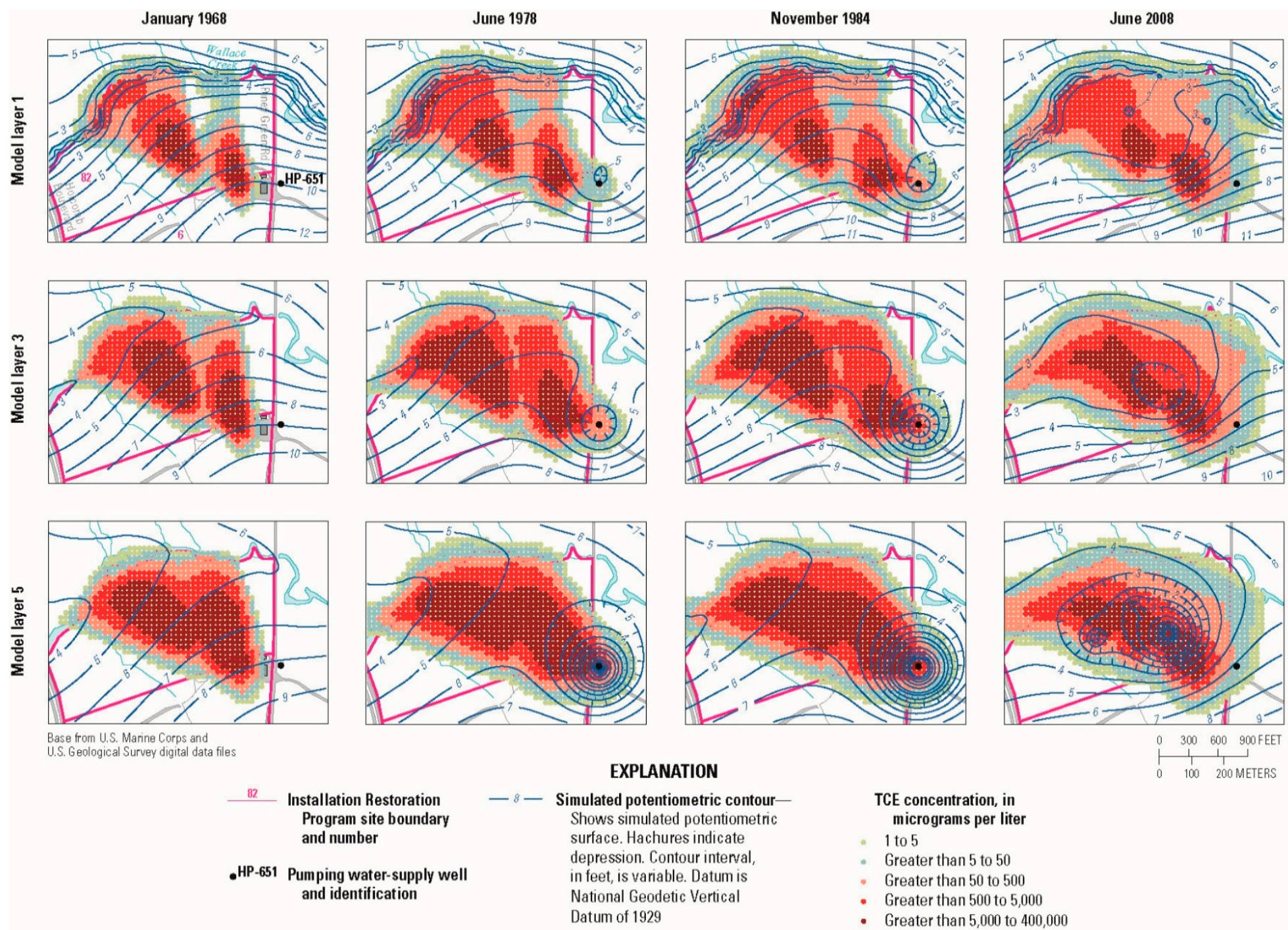

\section{EXPLANATION}

lated potentiometric contour-

TCE concentration, in micrograms per liter - 1 to 5

- Greater than 5 to 50

- Greater than 50 to 500

- Greater than 500 to 5,000

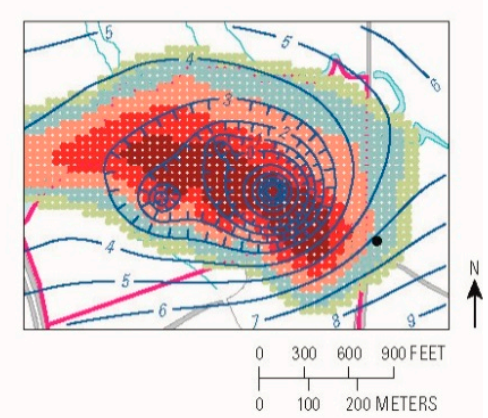

20 of 34 and identification

Figure 8. Reconstructed (simulated) water levels and distribution of trichloroethylene (TCE) within the Hadnot Point landfill (HPLF) area fate and transport model subdomain, model layers 1, 3, and 5, U.S. Marine Corps Base Camp Lejeune, North Carolina (from [1]; $1 \mathrm{ft}=0.3048 \mathrm{~m}$ ). 
and November 1984), to dilution and reduction in the TCE concentration at the end of the historical reconstruction simulation (June 2008) because of the cessation of pumping of historically contaminated HPIA water-supply wells. Similar areal maps were constructed for benzene migration within the HPIA and are described and provided in $[1,36]$.

The areal distributions of reconstructed TCE concentrations for model layers 1, 3, and 5 within the HPLF for four periods-January 1968, June 1978, November 1984, and June 2008-are shown in Figure 8. Model layers 1, 3, and 5 represent major water-bearing units in the study area and are correlated with the Brewster Boulevard aquifer system, the Tarawa Terrace aquifer, and the Upper Castle Hayne aquifer, respectively [1] (Table A11). The TCE source occurring within the fate and transport model subdomain representing the HPLF was assigned to model layers 1-7 (Table 3). Viewed synoptically, the maps in Figure 8 illustrate a progression in the vertical (by model layer) and areal distribution of TCE within the HPLF area. January 1968 coincides with the start of the core period for the epidemiological studies, but a time prior to the onset of pumping at well HP-651. By January 1968, simulated TCE contamination within the HPLF area had migrated vertically downward to the Upper Castle Hayne aquifer, corresponding to model layer 5. June 1978 and November 1984 represent periods of substantial impact of watersupply well HP-651 on groundwater flow and the migration of TCE within the HPLF area. In the model, watersupply well HP-651 is pumping 100 percent from the Upper Castle Hayne aquifer (layer 5), and this effect is seen by the large cone of depression centered at, and migration of TCE to, well HP-651 during June 1978 and November 1984 (Figure 8). Reduction in TCE concentrations began when well HP-651 was taken out of service during February 1985 [10,11] (CLW \#4913). By June 2008, a shift in the simulated center of mass of the TCE plume in a northwesterly direction from well HP-651 is clearly seen in Figure 8. This shift in the center of mass of TCE is primarily caused by the influence of Wallace Creek (Figure 5b) on local groundwater flow and is more pronounced in model layers 1 and 3. Note, remediation extraction well operations began during October 1996 and pumped from model layer 5 [9] (pp. C46-C51). Similar areal maps were constructed for PCE migration within the HPLF area and are described and provided in [1,36].

\subsection{Reconstructed Drinking-Water Concentrations}

Using reconstructed (simulated) water-supply well concentrations, monthly mean concentrations of TCE were estimated for drinking water at the Hadnot Point WTP. In addition, monthly mean concentrations for PCE, 1,2tDCE, vinyl chloride and benzene also were estimated using the approaches and methods described herein. Reconstructed monthly mean concentrations of VOCs in drinking water delivered by the Hadnot Point WTP and measured concentrations in drinking water at the WTP are shown in Figure 9 along with the current MCL for each contaminant. Measured concentrations also are listed in Table 5. Monthly reconstructed concentrations at the Hadnot Point WTP for the entire historical period (1942-2008) are provided in [1] (Appendix A7). Of note in Figure 9 is the effect of the contribution of TCE-contaminated groundwater when pumping began at water-supply well HP651 (July 1972). TCE concentrations in drinking water at the Hadnot Point WTP ranged from about 10 to $30 \mu \mathrm{g} / \mathrm{L}$ for the period 1955-1972, prior to the onset of pumping from water-supply well HP-651. Subsequent to the onset of pumping of water-supply well HP-651 during July 1972, simulated drinking water contaminant concentrations increased to a maximum computed value of $783 \mu \mathrm{g} / \mathrm{L}$ during November 1983. It is also important to note that each VOC shown in Figure 9 was assumed to be an independent contaminant with no chemical mixing or degradation by-products. Given the limited number of measured drinking-water concentration data and their substantial variations, there is reasonable agreement between measured drinking-water concentrations and historical reconstruction results for the Hadnot Point WTP. 


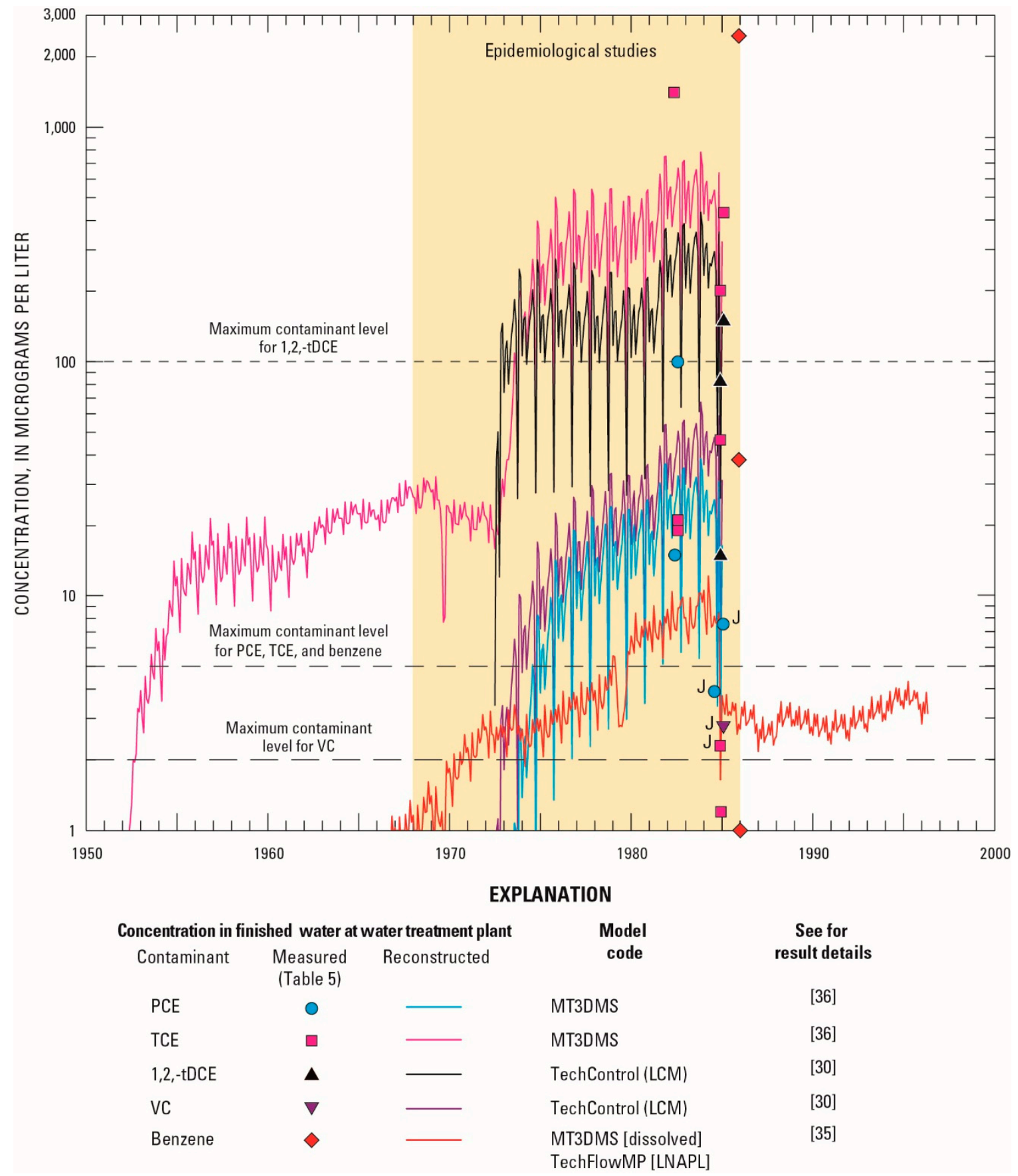

Figure 9. Reconstructed (simulated) drinking-water and measured concentrations of tetrachloroethylene (PCE), trichloroethylene (TCE), trans-1,2-dichloroethylene (1,2-tDCE), vinyl chloride (VC), and benzene at the Hadnot Point water treatment plant, U.S. Marine Corps Base Camp Lejeune, North Carolina. (See [1] for a listing of monthly mean drinking-water concentrations; J, estimated; LCM, linear control model; LNAPL, light nonaqueous phase liquid.) 
Table 5. Selected measured and reconstructed (simulated) concentrations of tetrachloroethylene (PCE), trichloroethylene (TCE), trans-1,2-dichloroethylene (1,2tDCE), vinyl chloride (VC), and benzene at the Hadnot Point water treatment plant, U.S. Marine Corps Base Camp Lejeune, North Carolina.

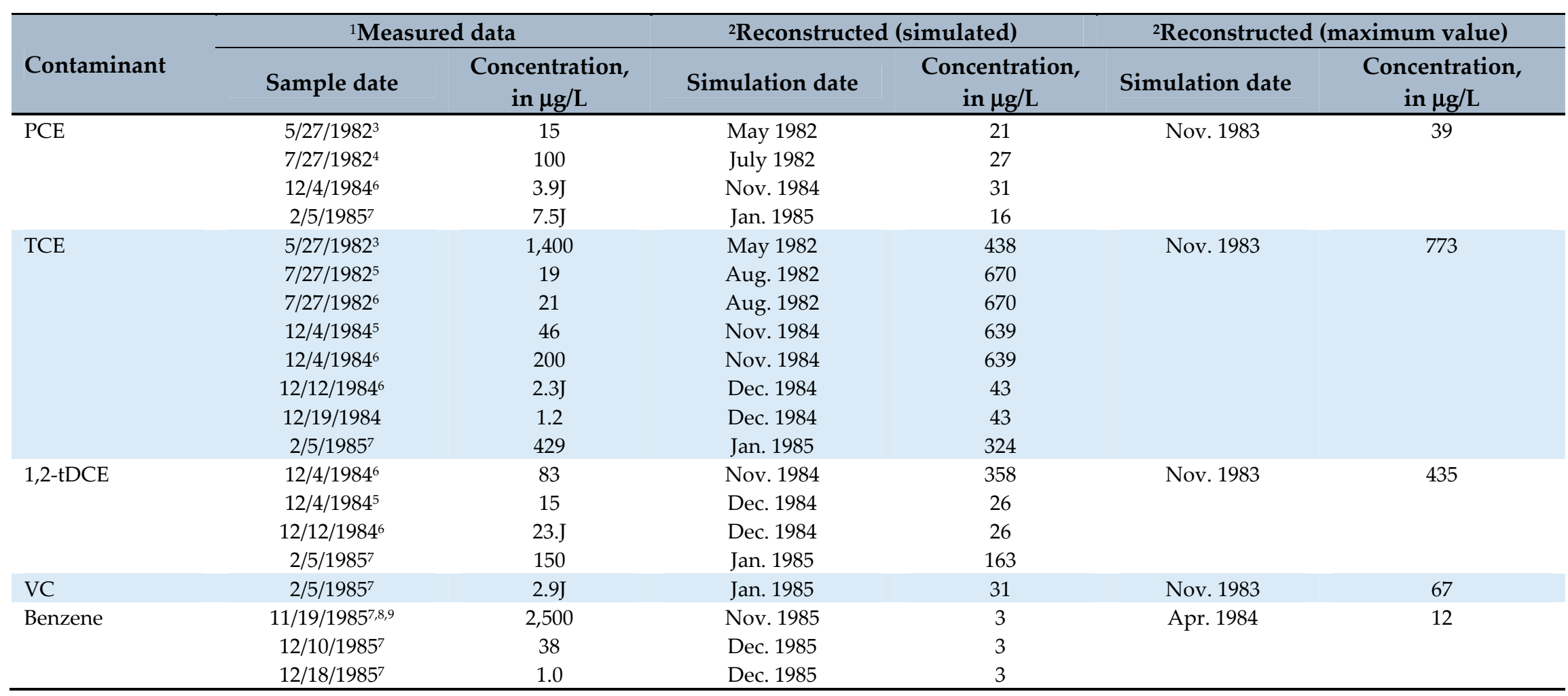

${ }^{1}$ Data from [9] (Tables C11, C12);

${ }^{2}$ Simulation results represent the last day of each month (e.g., May 31); results reported for simulation month nearest the sample date; refer to [1] (Appendix A7) for complete listing of reconstructed treated-water concentrations;

${ }^{3}$ Water sample collected at Building NH-1; data reported as unreliable; ${ }^{4}$ Water sample collected at Building FC-530; ${ }^{5}$ Untreated water; ${ }^{6}$ Treated water;

${ }^{7}$ Treatment status unknown; ${ }^{8}$ Laboratory analysis noted with: "Sample appears to have been contaminated with benzene, toluene, and methyl chloride" [49];

9Data noted with: "Not Representative" [11] (CLW \#1356). 

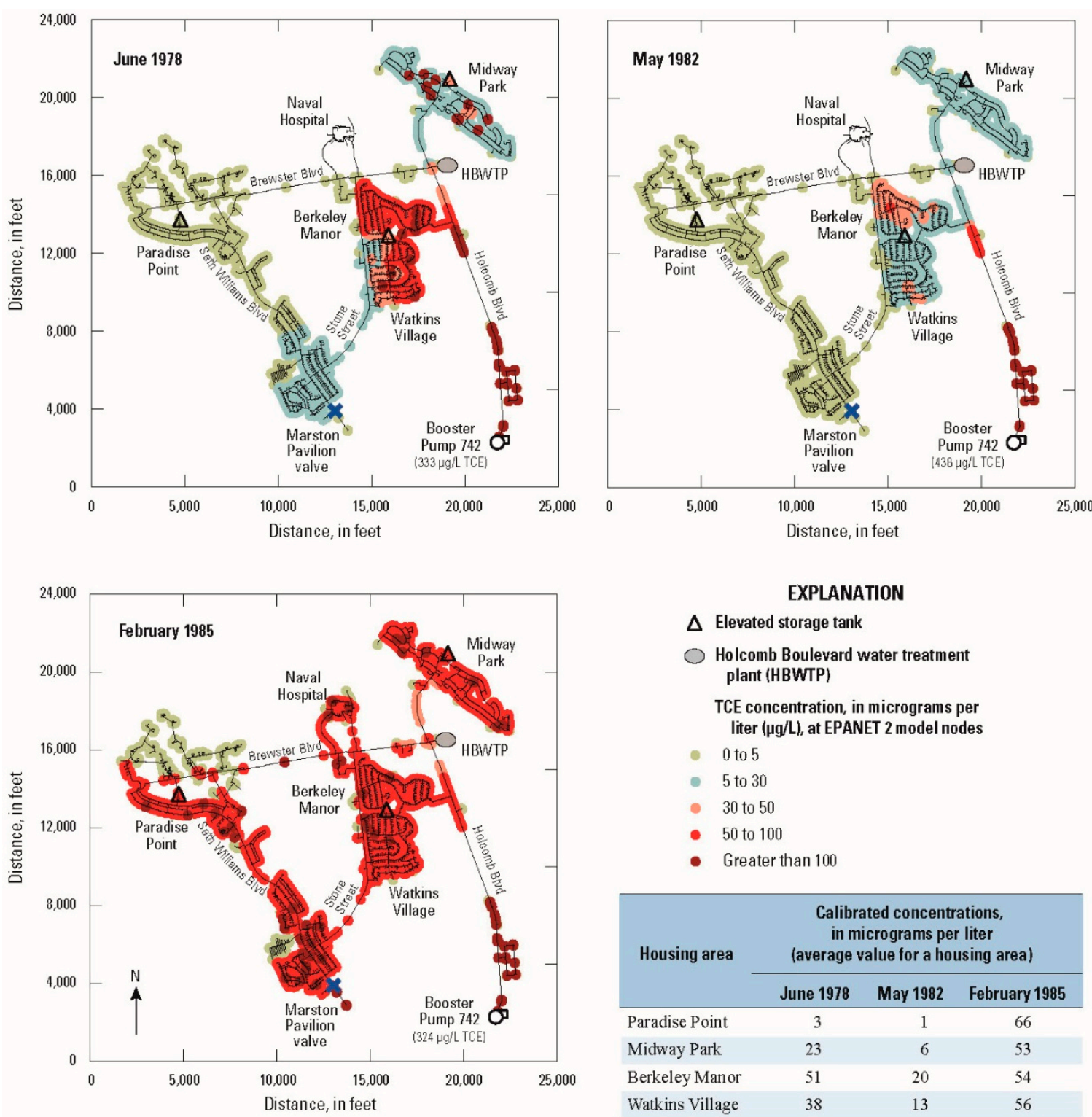

\begin{tabular}{|c|c|c|c|}
\hline \multirow[t]{2}{*}{ Housing area } & \multicolumn{3}{|c|}{$\begin{array}{l}\text { Calibrated concentrations, } \\
\text { in micrograms per liter } \\
\text { (average value for a housing area) }\end{array}$} \\
\hline & June 1978 & May 1982 & February 1985 \\
\hline Paradise Point & 3 & 1 & 66 \\
\hline Midway Park & 23 & 6 & 53 \\
\hline Berkeley Manor & 51 & 20 & 54 \\
\hline Watkins Village & 38 & 13 & 56 \\
\hline
\end{tabular}

Figure 10. Reconstructed (simulated) distribution of trichloroethylene (TCE) contamination within the Holcomb Boulevard water treatment plant service area resulting from supply of contaminated Hadnot Point drinking water, June 1978, May 1982, and February 1985 (from [1,12]; $1 \mathrm{ft}=0.3048 \mathrm{~m}$ ).

\subsection{Intermittent Transfers of Contaminated Drinking Water}

Spatial distributions of TCE levels within Holcomb Boulevard housing areas for three time periods - June 1978, May 1982, and February 1985-are shown in Figure 10. These historical reconstruction results were obtained using the EPANET 2 water-distribution system model for interconnection events. The Holcomb Boulevard reconstructed drinking-water mean TCE concentrations for the Berkeley Manor and Watkins Village housing areas during June 1978 are $51 \mu \mathrm{g} / \mathrm{L}$ and $38 \mu \mathrm{g} / \mathrm{L}$, respectively. For May 1982, the Berkeley Manor and Watkins Village housing areas show reconstructed mean TCE concentrations of $20 \mu \mathrm{g} / \mathrm{L}$ and $13 \mu \mathrm{g} / \mathrm{L}$, respectively. During the 8-day period of January 28-February 4, 1985 (represented by the February 1985 map in Figure 10), when the Holcomb Boulevard WTP was shut down, the reconstructed mean TCE concentrations in all housing areas exceeded $50 \mu \mathrm{g} / \mathrm{L}$ with the exception of the northernmost extent of Paradise Point and a small area to the north of the Marston Pavilion valve (the current MCL for TCE in drinking water is $5 \mu \mathrm{g} / \mathrm{L}$ ). Overall, during intermittent transfers of contaminated Hadnot Point drinking water, the Paradise Point family housing area shows the lowest reconstructed mean TCE concentrations, whereas Berkeley Manor followed by Watkins Village show the greatest reconstructed mean TCE concentrations (except for the pipeline that directly connects booster pump 742 to the Holcomb Boulevard water- 
distribution system along Holcomb Boulevard). Spatial distribution maps for the other contaminants of concern (similar to Figure 10) are provided in [12]. Reconstructed concentrations for the other contaminants of concern (PCE, 1,2-tDCE, vinyl chloride, and benzene) rarely equaled or exceeded their current MCLs during interconnection periods of interest to the ATSDR health studies.

In summary, historical reconstruction of drinking-water contaminant concentrations at the Hadnot Point WTP estimated that TCE concentrations reached a maximum value of $783 \mu \mathrm{g} / \mathrm{L}$ compared to a measured value of 1,400 $\mu \mathrm{g} / \mathrm{L}$ during the period August 1953-December 1984 (Table 5, Figure 9). The Hadnot Point WTP also provided contaminated drinking water to the Holcomb Boulevard housing area continuously prior to June 1972, when the Holcomb Boulevard WTP came on line (maximum reconstructed TCE concentration of $32 \mu \mathrm{g} / \mathrm{L}$ ) and intermittently during the period June 1972-February 1985, with an estimated maximum reconstructed TCE concentration of 66 $\mu \mathrm{g} / \mathrm{L}$ (Figure 10).

\subsection{Sensitvity and Uncertainty Analyses}

Best modeling practice requires that evaluations be conducted to ascertain confidence in models and model results by assessing parameter sensitivity, variability, and uncertainty associated with the modeling process and with the outcomes attributed to models [43,50]. There are numerous methods for characterizing a model's sensitivity and uncertainty based on variations of calibrated parameter values [43,50-53]. These methods are generally classified into two groups: (1) sensitivity analysis, wherein calibrated model parameter values are varied either manually or through some automated method, and (2) probabilistic uncertainty analysis, wherein probabilistic methods are used to characterize and quantify the input and output parameter variation and uncertainty. Substantial numbers of sensitivity and uncertainty analyses were conducted as part of this study.

Table 6. Types of sensitivity analyses applied to models and parameters (from [1]).

\begin{tabular}{|c|c|c|c|}
\hline & & TYPE OF VARIATION & \\
\hline & & Physical parameters & Numerical parameters \\
\hline 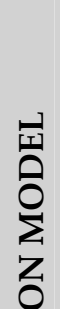 & $\begin{array}{l}3 \\
0 \\
4 \\
4 \\
0 \\
0 \\
3 \\
0 \\
0 \\
\Xi \\
0 \\
0 \\
0\end{array}$ & $\begin{array}{l}\text { Historical monthly pumping: } Q_{\text {monthly }} \\
\text { Input parameters/hydraulics: } K_{x x}\end{array}$ & Cell size: $\Delta x, \Delta y$ \\
\hline 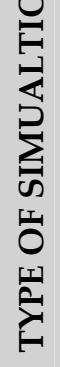 & 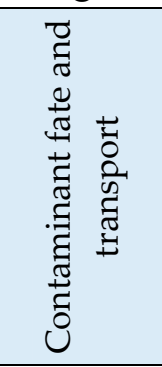 & $\begin{array}{l}\text { Input parameters/fate and transport: } \rho_{t}, n_{E}, \alpha_{L}, K_{D}, \\
\lambda, C \\
\text { Benzene source area and release } \\
\text { Trichloroethylene source-release date }\end{array}$ & $\begin{array}{l}\text { Cell size: } \Delta x, \Delta y \\
\text { Time-step size: } \Delta t\end{array}$ \\
\hline & 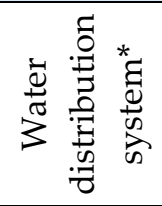 & $\begin{array}{l}\text { Pipe roughness: C-factor } \\
\text { Storage-tank mixing }\end{array}$ & Demand factor \\
\hline
\end{tabular}

*Sensitivity analyses using water-distribution system model conducted as part of the Tarawa Terrace study area [46].

Sensitivity analyses were conducted for groundwater-flow, contaminant fate and transport, and waterdistribution system models. These analyses assessed variations in physical parameters (e.g., historical monthly pumping, source-release dates, and storage-tank mixing) and numerical parameters (e.g., model-grid cell size, time- 
step size, and demand factors). For example, sensitivity analysis results for the TCE source-release date within the HPIA indicate that TCE concentrations in drinking water at the Hadnot Point WTP could have exceeded the current MCL of $5 \mu \mathrm{g} / \mathrm{L}$ as early as November 1948 compared to the calibrated exceedance date of August 1953. A summary of the types of sensitivity analyses that were conducted is listed in Table 6; substantive details on these analyses and results are provided in [1].

Probabilistic uncertainty analyses were also conducted as part of this study to characterize uncertainty of model output (simulated concentrations) due to model input-parameter uncertainty and variation. Selected probabilistic analyses using Monte Carlo simulations were conducted. Owing to brevity, an example using the Latin hypercube sampling methodology is presented herein. Additional detailed analyses are provided in [1]. In this analysis revised pumping schedules (relative to the calibrated schedules reported in [29]) were used as inputs to the contaminant fate and transport models to reconstruct TCE concentrations delivered to the Hadnot Point WTP by each well. Reconstructed TCE concentrations at the Hadnot Point WTP derived from applying the Latin hypercube methodology to water-supply well monthly operational schedules are shown in Figure 11. In this figure, the black (thicker solid) line indicates the TCE concentration obtained from the calibrated models. The gray (thinner) lines indicate the TCE concentration variation over time for the 10 random scenarios obtained by Latin hypercube methodology. Results shown in Figure 11 indicate that observed data exhibit substantially greater variation than reconstructed concentrations generated using the uncertainty analysis. An additional observation is that for some historical months, the calibrated TCE concentration exceeds the probabilistic concentrations simulated by the Monte Carlo-Latin hypercube sampling methodology. This could be a result of a number of factors such as (1) the type of probability density function assigned to model parameters, (2) the use of solely 10 random scenarios obtained by the Latin hypercube sampling methodology, (3) the uncertainty and lack of continuous monthly water-supply well operational data, (4) the number of Monte Carlo realizations used, or (5) a combination of any of the above factors.

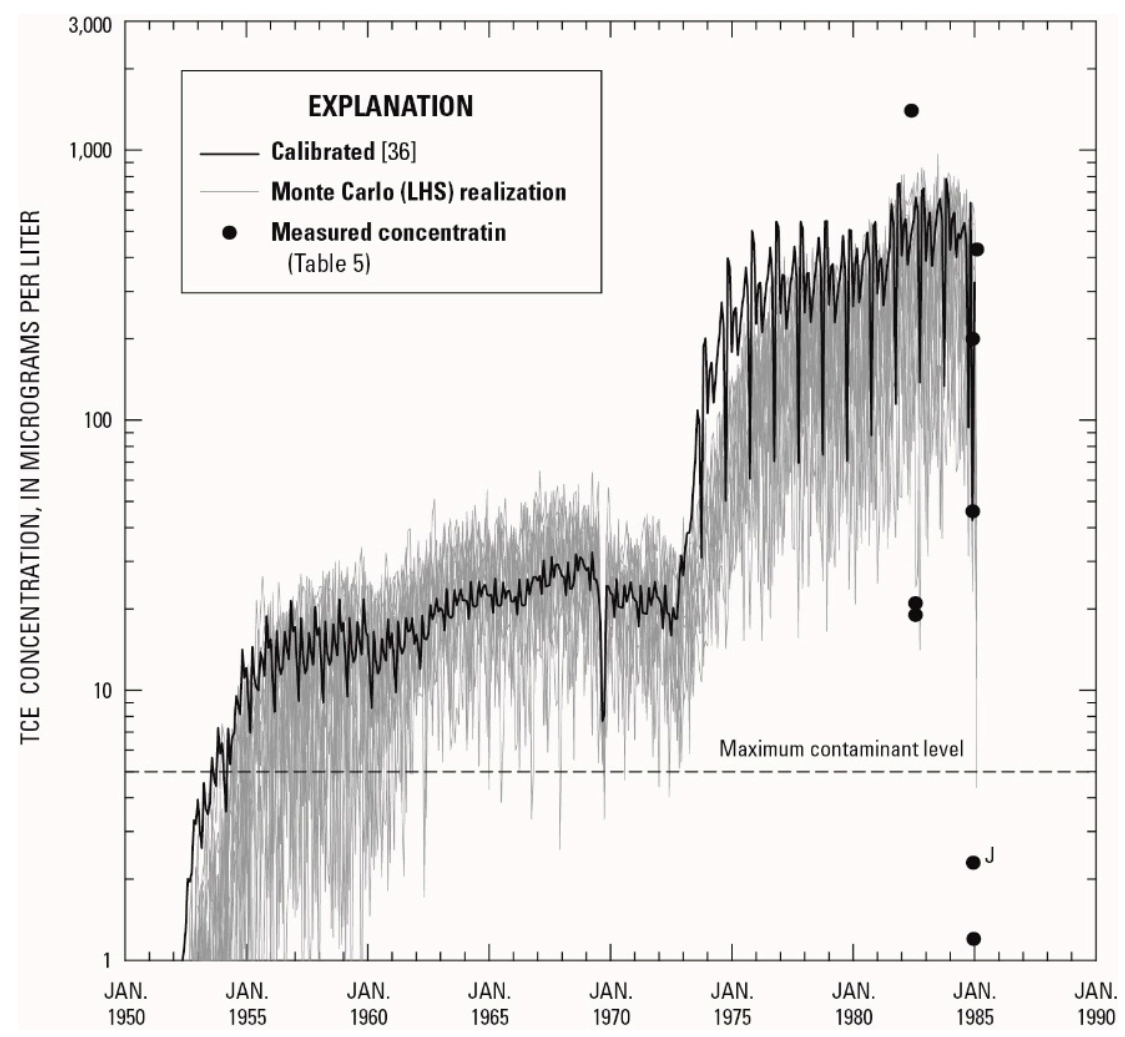

Figure 11. Variations in reconstructed (simulated) drinking-water concentrations of trichloroethylene (TCE) derived using Latin hypercube sampling (LHS) methodology on water-supply well monthly operational schedules at the Hadnot Point water treatment plant, U.S. Marine Corps Base Camp Lejeune, North Carolina (from [1,29]; J, estimated). 


\section{Discussion}

ATSDR conducted and completed a series of epidemiological studies to evaluate the potential for health effects from exposures to VOCs (PCE, TCE, 1,2-tDCE, vinyl chloride, and benzene) in drinking water at USMCB Camp Lejeune, North Carolina, which were recently published [23-27]. These health studies required knowledge of contaminant concentrations in drinking water-at monthly intervals-delivered to family housing, enlisted personnel barracks, and workplaces within the study area. The historical reconstruction process, which included information and data mining activities and water-modeling methods, was used to quantify estimates of monthly mean contaminant-specific concentrations. Results obtained from the historical reconstruction process, watermodeling methods, and base-housing records were used in the aforementioned epidemiological studies to estimate the level and duration of exposures. Based on data, analyses, interpretations, model calibrations, and sensitivity and uncertainty analyses, the historical reconstruction process provides evidence that drinking-water TCE concentrations at the Hadnot Point WTP substantially exceeded its MCL $(5 \mu \mathrm{g} / \mathrm{L})$ during the periods assessed in the ATSDR epidemiological studies (Figure 12). It is most likely that in Hadnot Point drinking water TCE first exceeded its current MCL during August 1953, but this exceedance could have been as early as November 1948 if releases of TCE to the subsurface began during or immediately following the onset of construction (1941/1942) of USMCB Camp Lejeune. Drinking-water contaminated with PCE exceeded the MCL for PCE (5 $\mu \mathrm{g} / \mathrm{L})$ during the period 19751985 for the Hadnot Point study area and during the period 1957-1987 for the Tarawa Terrace study area (Figure 12); 1,2-tDCE and vinyl chloride also exceeded their respective MCLs (100 $\mu \mathrm{g} / \mathrm{L}$ and $2 \mu \mathrm{g} / \mathrm{L}$, respectively) during the period 1975-1985 (Figure 9). Although substantial volumes of fuel were lost due to leakage to the subsurface during a period of about 40 years (range of 0.9 to 1.6 million gallons, [1,31]), benzene concentrations in drinking water only slightly exceeded the MCL (5 $\mu \mathrm{g} / \mathrm{L})$ during the period 1980-1985 (Figure 9). Within the Holcomb Boulevard housing area, except for the 8-day period of January 28-February 4, 1985, when the Holcomb Boulevard WTP was out of service, only TCE routinely exceeded its MCL during intermittent periods of connection with the Hadnot Point water-distribution system.

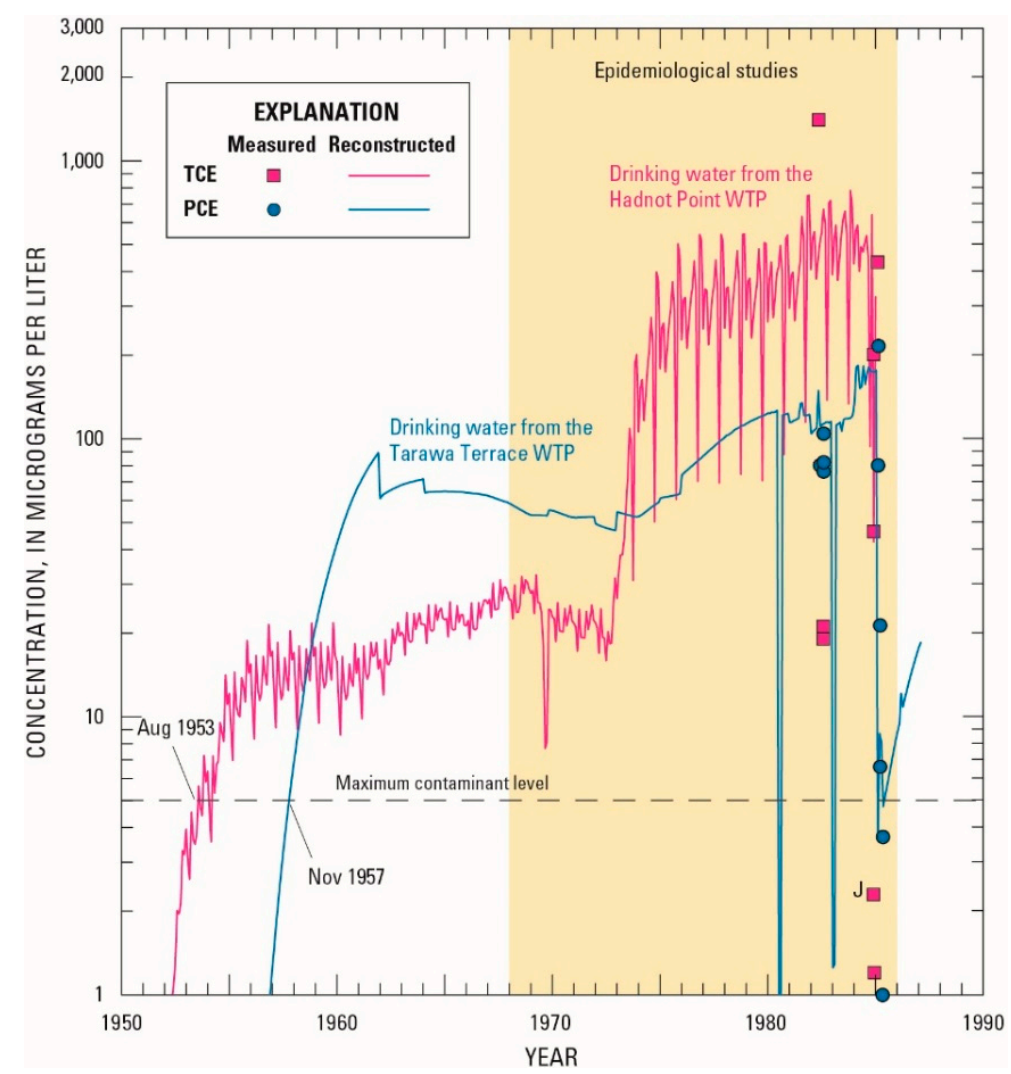

Figure 12. Reconstructed (simulated) drinking-water and measured concentrations of tetrachloroethylene (PCE) and trichloroethylene (TCE) at the Tarawa Terrace and Hadnot Point water treatment plants, U.S. Marine Corps Base Camp Lejeune, North Carolina (from $[1,4,5]$ ). 
ATSDR has completed five epidemiological studies using the monthly mean drinking-water concentration estimates derived by the historical reconstruction process. These studies were: (1) a birth defects and childhood cancer (case-control) study [23], (2) an adverse birth outcome (cross-sectional) study [24], (3) a male breast cancer (case-control) study [25], (4) a mortality study of Marines and Navy personnel (retrospective cohort study) [26], and (5) a mortality study of civilian employees (a retrospective cohort study) at USMB Camp Lejeune [27]. Methods, analyses and results specific to each study are provided in [23-27]. The ATSDR epidemiological studies would not have been able to evaluate exposure-response relationships without the monthly mean drinking-water concentrations produced by the historical reconstruction process. Additionally, the monthly mean concentrations allowed for trimester-specific exposures to be calculated for the studies of adverse birth outcomes, including specific birth defects, and childhood hematopoietic cancers at Camp Lejeune. The ability to evaluate chemical-specific associations and exposure-response trends, rather than simply comparing exposed to unexposed, greatly enhanced the impact of these studies and the evidence they provided.

\section{Conclusions}

Given the lack and substantial limitation of historical data, multiple lines of evidence and multiple methods of analyses were used to derive water-modeling results obtained using the historical reconstruction process. These included substantial efforts in information gathering and data mining, water-modeling methods, and sensitivity and probabilistic analyses. These results provide reasonable to good agreement between measured drinking-water concentrations and reconstructed results. The results presented herein allowed epidemiologists to categorize exposure into several categories rather than relying on crude classification estimates of exposed versus unexposed populations for the epidemiological studies at USMCB Camp Lejeune, North Carolina. The ability to evaluate exposure-response trends, rather than simply comparing exposed to unexposed, greatly enhanced the impact of these studies and the evidence they provided.

Acknowledgments: A number of colleagues participated in and contributed to the water-modeling analyses summarized herein. They are (in alphabetical order): B.A. Anderson (ATSDR), B. Chang (GT-MESL and Eastern Research Group), R.E. Faye (R.E. Faye \& Associates), W.M. Grayman (W.M. Grayman Consulting Engineer), J. Guan (GT-MESL), L.E. Jones (U.S. Geological Survey), S.M. Moore (ATSDR), J.B. Sautner (ATSDR), R.J. Suárez-Soto (ATSDR), and I.T. Telci (GT-MESL and Eastern Research Group). The authors acknowledge the following organizations for assisting with information and data reported herein: U.S. Geological Survey (North Carolina and Georgia Water Science Centers), USMB Camp Lejeune (Environmental Management Division and Public Works Utility Section), Eastern Research Group, Inc., and the Multimedia Environmental Simulations Laboratory (School of Civil and Environmental Engineering, Georgia Institute of Technology). The authors greatly acknowledge Caryl J. Wipperfurth and Kimberly A. Waltenbaugh, U.S. Geological Survey Science Publishing Network, for their expert and highly professional assistance in the preparation of illustrations and tables. Finally, the authors acknowledge members of the USMCB Camp Lejeune Community Assistance Panel (CAP). In particular, Jerome M. Ensminger (USMC, Retired), Michael S. Partain, and Tom Townsend (USMC, Retired) are acknowledged for their input, dogged review of the many historical documents, and perspectives on historical activities at USMCB Camp Lejeune.

Author Contributions: All authors contributed to the research discussed in this article. M. L. Maslia oversaw and directed the water-modeling analyses and M. M. Aral contributed to the development of the water-supply well operation reconstructions, numerical modeling, and probabilistic analysis. P. Z. Ruckart and F. J. Bove developed the epidemiological studies protocols for application of water-modeling analyses and conducted the epidemiological studies.

Conflicts of Interest: The authors declare no conflict of interest. 


\section{Abbreviations}

The following abbreviations are used in this manuscript:

AST/UST: above ground storage tank/underground storage tank

ATSDR: Agency for Toxic Substances and Disease Registry

BTEX: benzene, toluene, ethylbenzene, and xylene

C: source concentration

CLW: Camp Lejeune water document

EPANET 2: water-distribution system model developed by the USEPA

EPS: extended period simulation

$\mathrm{ft}$ : foot or feet

GIS: geographical information system

HPIA: Hadnot Point Industrial Area

HPFF: Hadnot Point fuel farm

HPLF: Hadnot Point landfill

I: infiltration

IRP: Installation Restoration Program of the U.S. Department of the Navy

$K_{D}$ : distribution coefficient

$\mathrm{km}$ : kilometer or kilometers

$K_{x x}, K_{z z}$ : horizontal and vetical hydraulic conductivity

LNAPL: light nonaqueous-phase liquid

$\mathrm{m}$ : meter or meters

MCL: maximum contaminant level

$\mathrm{mg} / \mathrm{L}:$ milligram per liter

mi: mile or miles

MODFLOW: modular, three-dimensional groundwater flow model developed by the United States Geological Survey $n_{E}$ : porosity

PCE: tetrachloroethylene

$Q_{\text {monthly: historical monthly pumping }}$

TCE: trichloroethylene

USEPA: United States Environmental Protection Agency

USMCB: United States Marine Corps Base

VC: vinyl chloride

VOC: volatile organic compound

WTP: water treatment plant

$\alpha_{\mathrm{L},} \alpha_{T}, \alpha_{V}$ : longitudinal, transverse, and vetical dispersivity

$\Delta t$ : time-step size

$\Delta x, \Delta y$ : finite-difference cell size

$\lambda$ : biodegradation rate

$\rho_{b}$ : bulk density

$\mu \mathrm{g} / \mathrm{L}$ : micrograms per liter

1,2-tDCE: trans-1,2-dichloroethylene 


\section{References}

1. Maslia, M.L.; Suárez-Soto, R.J.; Sautner, J.B.; Anderson, B.A.; Jones, L.E.; Faye, R.E.; Aral, M.M.; Guan, J.; Jang, W.; Telci, I.T.; Grayman, W.M.; Bove, F.J.; Ruckart, P.Z.; Moore, S.M. Analyses and Historical Reconstruction of Groundwater Flow, Contaminant Fate and Transport, and Distribution of Drinking Water Within the Service Areas of the Hadnot Point and Holcomb Boulevard Water Treatment Plants and Vicinities, U.S. Marine Corps Base Camp Lejeune, North CarolinaChapter A: Summary and Findings, Agency for Toxic Substances and Disease Registry, Atlanta, GA, USA, March 2013. Available online: http://www.atsdr.cdc.gov/sites/lejeune/docs/chapter_A_hadnotpoint.pdf (accessed 29 July 2016).

2. Lawrence, S.J. Analyses of Groundwater Flow, Contaminant Fate and Transport, and Distribution of Drinking Water at Tarawa Terrace and Vicinity, U.S. Marine Corps Base Camp Lejeune, North Carolina: Historical Reconstruction and Present-Day Conditions-Chapter D: Properties of Degradation Pathways of Common Organic Compounds in Groundwater, Agency for Toxic Substances and Disease Registry, Atlanta, GA, USA, September 2007. Available online: http://www.atsdr.cdc.gov/sites/lejeune/docs/Chapter\%20D_TarawaTerrace.pdf (cited 29 July 2016).

3. USEPA (U.S. Environmental Protection Agency). National Primary Drinking Water Standards, Report No.: EPA 816-F-09004, Washington, DC, USA, May 2009.

4. Maslia, M.L.; Sautner, J.B.; Faye, R.E.; Suárez-Soto, R.J.; Aral, M.M.; Grayman, W.M.; Jang, W.; Wang, J.; Bove, F.J.; Ruckart, P.Z.; Valenzuela, C.; Green, J.W. Jr.; Krueger, A.L. Analyses of Groundwater Flow, Contaminant Fate and Transport, and Distribution of Drinking Water at Tarawa Terrace and Vicinity, U.S. Marine Corps Base Camp Lejeune, North Carolina: Historical Reconstruction and Present-Day Conditions-Chapter A: Summary of Findings, Agency for Toxic Substances and Disease Registry, Atlanta, GA, USA, July $2007 . \quad$ Available online: http://www.atsdr.cdc.gov/sites/lejeune/docs/ChapterA_TarawaTerrace.pdf (accessed 29 July 2016).

5. Maslia, M.L.; Aral, M.M.; Faye, R.E.; Suárez-Soto, R.J.; Sautner, J.B.; Wang, J.; Jang, W.; Bove, F.J.; Ruckart, P.Z. Reconstructing Historical Exposures to Volatile Organic Compound-Contaminated Drinking Water at a U.S. Military Base. Water Quality, Exposure and Health. 2009, 1, 49-68.

6. NTP (National Toxicology Program). 12 $2^{\text {th }}$ Report on Carcinogens. U.S. Department of Health and Human Services, Public Health Service, Research Triangle Park, NC, USA, June 2011.

7. Guha, N.; Loomis, D.; Grosse, Y.; et al. Carcinogenicity of Trichloroethylene, Tetrachloroethylene, some other Chlorinated Solvents, and their Metabolites. The Lancet Oncology. 2012, 13, 1192-1193.

8. Watson, A.D. Onslow County, A Brief History. North Carolina Division of Archives and History: Raleigh, NC, USA; 1995.

9. Faye, R.E.; Anderson, B.A.; Suárez-Soto, R.J.; Sautner, J.B. Analyses and Historical Reconstruction of Groundwater Flow, Contaminant Fate and Transport, and Distribution of Drinking Water Within the Service Areas of the Hadnot Point and Holcomb Boulevard Water Treatment Plants and Vicinities, U.S. Marine Corps Base Camp Lejeune, North CarolinaChapter C: Occurrence of Selected Contaminants in Groundwater at Installation Restoration Program Sites, Agency for Toxic Substances and Disease Registry, Atlanta, GA, USA, October 2010. Available online: http://www.atsdr.cdc.gov/sites/lejeune/docs/chapter_c_hadnotpoint.pdf (accessed 29 July 2016).

10. Sautner, J.B.; Anderson, B.A.; Suárez-Soto, R.J.; Maslia, M.L. Descriptions and Characterizations of Data Pertinent to WaterSupply Well Capacities, Histories, and Operations-Supplement 1. In: Maslia, M.L.; Suárez-Soto, R.J.; Sautner, J.B.; Anderson, B.A.; Jones, L.E.; Faye, R.E.; Aral, M.M.; Guan, J.; Jang, W.; Telci, I.T.; Grayman, W.M.; Bove, F.J.; Ruckart, P.Z.; Moore, S.M. Analyses and Historical Reconstruction of Groundwater Flow, Contaminant Fate and Transport, and Distribution of Drinking Water Within the Service Areas of the Hadnot Point and Holcomb Boulevard Water Treatment Plants and Vicinities, U.S. Marine Corps Base Camp Lejeune, North Carolina-Chapter A: Summary and Findings, Agency for Toxic Substances and Disease Registry, Atlanta, GA, USA, March 2013. Available online: http://www.atsdr.cdc.gov/sites/lejeune/docs/chapter_A_hadnotpoint.pdf (accessed 29 July 2016).

11. CLW, Camp Lejeune Water Documents, 0001-8761 (not consecutively available), provided on CD-ROM format. In: Maslia, M.L.; Sautner, J.B.; Faye, R.E.; Suárez-Soto, R.J.; Aral, M.M.; Grayman, W.M.; Jang, W.; Wang, J.; Bove, F.J.; Ruckart, P.Z.; Valenzuela, C.; Green, J.W. Jr.; Krueger, A.L. Analyses of Groundwater Flow, Contaminant Fate and Transport, and Distribution of Drinking Water at Tarawa Terrace and Vicinity, U.S. Marine Corps Base Camp Lejeune, North Carolina: Historical Reconstruction and Present-Day Conditions-Chapter A: Summary of Findings, Agency for Toxic Substances and Disease Registry, Atlanta, GA, USA, July $2007 . \quad$ Available online: http://www.atsdr.cdc.gov/sites/lejeune/docs/ChapterA_TarawaTerrace.pdf (accessed 29 July 2016). 
12. Sautner, .JB.; Grayman, W.M.; Telci, I.T.; Maslia, M.L.; Aral, M.M. Field Tests, Data Analyses, and Simulation of the Distribution of Drinking Water with Emphasis on Intermittent Transfers of Drinking Water Between the Hadnot Point and Holcomb Boulevard Water-Distribution Systems-Supplement 8. In: Maslia, M.L.; Suárez-Soto, R.J.; Sautner, J.B.; Anderson, B.A.; Jones, L.E.; Faye, R.E.; Aral, M.M.; Guan, J.; Jang, W.; Telci, I.T.; Grayman, W.M.; Bove, F.J.; Ruckart, P.Z.; Moore, S.M. Analyses and Historical Reconstruction of Groundwater Flow, Contaminant Fate and Transport, and Distribution of Drinking Water Within the Service Areas of the Hadnot Point and Holcomb Boulevard Water Treatment Plants and Vicinities, U.S. Marine Corps Base Camp Lejeune, North Carolina-Chapter A: Summary and Findings, Agency for Toxic Substances and Disease Registry, Atlanta, GA, USA, March 2013. Available online: http://www.atsdr.cdc.gov/sites/lejeune/docs/chapter_A_hadnotpoint.pdf (accessed 29 July 2016).

13. Faye, R.E.; Suárez-Soto, R.J.; Maslia, M.L. Analyses and Historical Reconstruction of Groundwater Flow, Contaminant Fate and Transport, and Distribution of Drinking Water Within the Service Areas of the Hadnot Point and Holcomb Boulevard Water Treatment Plants and Vicinities, U.S. Marine Corps Base Camp Lejeune, North Carolina-Chapter D: Occurrence of Selected Contaminants in Groundwater at Above-Ground and Underground Storage Tank Sites, Agency for Toxic Substances and Disease Registry, Atlanta, GA, USA, December 2012. Available online: http://www.atsdr.cdc.gov/sites/lejeune/docs/ChapterD.pdf (accessed 29 July 2016).

14. Shiver, R.A. Groundwater Investigation to Define the Source(s) of Tetrachloroethylene that Have Contaminated Three Community Water Supply Wells at Tarawa Terrace I, Camp Lejeune Marine Corps Base, Onslow County, North Carolina Department of Natural Resources and Community Development, Wilmington, NC, USA, December 1985.

15. Rodenbeck, S.E.; Maslia, M.L. Groundwater Modeling and GIS to Determine Exposure to TCE at Tucson. Practice Periodical of Hazardous, Toxic, and Radioactive Waste Management. 1998, 2, 53-61.

16. McLaren/Hart-ChemRisk. Oak Ridge Dose Reconstruction Project Summary Report, McLaren/Hart-ChemRisk, Alameda, CA, USA, March 2000.

17. Costas, K.; Knorr, R.S.; Condon, S.K. A Case-Control Study of Childhood Leukemia in Woburn, Massachusetts: The Relationship Between Leukemia Incidence and Exposure to Public Drinking Water. The Science of the Total Environment. 2002, 300, 23-35.

18. Reif, J.S.; Burch, J.B.; Nuckols, J.R.; Metzger, L., Ellington, D.; Anger, K.W. Neurobehavioral Effects of Exposure to Trichloroethylene Through a Municipal Water Supply. Environmental Research. 2003, 93, 248-258.

19. Kopecky, K.J.; Davis, S.; Hamilton, T.E.; Saporito, M.S.; Onstad, L.E. Estimation of Thyroid Radiation Doses for the Hanford Thyroid Disease Study: Results and Implications for Statistical Power of the Epidemiological Analyses. Health Physics. 2004, 87, 15-32.

20. Maslia, M.L.; Reyes, R.J.; Gillig, R.E.; Sautner, J.B.; Fagliano, J.B.; Aral, M.M. Public Health Partnerships Addressing Childhood Cancer Investigations: Case Study of Toms River, Dover Township, New Jersey, USA. International Journal of Hygiene and Environmental Health. 2005, 208, 45-54.

21. Samhel, J.; Devlin, D.; Paustenbach, D.; Hollins, D.; Gaffney S. The Role of Exposure Reconstruction in Occupational Human Health Risk Assessment: Current Methods and a Recommended Framework. Critical Reviews in Toxicology. 2010, 40, 799-843.

22. Rothman, K.J.; Greenland, S.; Lash, T.L. Modern Epidemiology, $3^{\text {rd }}$ ed., Lippincott Williams \& Wilkins: Philadelphia, PA, USA, 2008.

23. Ruckart, P.Z.; Bove, F.J.; Maslia, M. Evaluation of exposure to contaminated drinking water and specific birth defects and childhood cancers at Marine Corps Base Camp Lejeune, North Carolina: a case-control study. Environmental Health. 2013, 12, 1-10. Available online: http://www.ehjournal.net/content/12/1/104, (accessed 29 July 2016).

24. Ruckart, P.Z.; Bove, F.J.; Maslia, M. Evaluation of contaminated drinking water and preterm birth, small for gestational age, and birth weight at Marine Corps Base Camp Lejeune, North Carolina: a cross-sectional study. Environmental Health, 2014, 1-10. Available online: http://www.ehjournal.net/content/13/1/99 (accessed 29 July 2016).

25. Ruckart, P.Z.; Bove, F.J.; Shanley, E.; Maslia, M. Evaluation of contaminated drinking water and male breast cancer at Marine Corps Base Camp Lejeune, North Carolina: a case control study. Environmental Health, 2015, 14, 1-16. Available online: http://www.ehjournal.net/content/14/1/974 (accessed 29 July 2016).

26. Bove, F.J.; Ruckart, P.Z.; Maslia, M.; Larson, T.C. Evaluation of mortality among marines and navy personnel exposed to contaminated drinking water at USMC base Camp Lejeune: a retrospective cohort study. Environmental Health. 2014, 14, 114. Available online: http://www.ehjournal.net/content/13/1/10 (accessed 29 July 2016) 
27. Bove, F.J.; Ruckart, P.Z.; Maslia, M.; Larson, T.C. Mortality study of civilian employees exposed to contaminated drinking water at USMC Base Camp Lejeune: a retrospective cohort study. Environmental Health. 2014, 13, 1-13. Available online: http://www.ehjournal.net/content/13/1/68 (accessed 29 July 2016).

28. Grayman, W.M.; Maslia, M.L.; Sautner, J.B. Calibrating Distribution Systems Models with Fire-Flow Tests. American Water Works Association, Optflow. 2006, 32, 10-12.

29. Telci, I.T.; Sautner, J.B.; Suárez-Soto, R.J.; Anderson, B.A.; Maslia, M.L.; Aral, M.M. Development and Application of a Methodology to Characterize Present-Day and Historical Water-Supply Well Operations-Supplement 2. In: Maslia, M.L.; Suárez-Soto, R.J.; Sautner, J.B.; Anderson, B.A.; Jones, L.E.; Faye, R.E.; Aral, M.M.; Guan, J.; Jang, W.; Telci, I.T.; Grayman, W.M.; Bove, F.J.; Ruckart, P.Z.; Moore, S.M. Analyses and Historical Reconstruction of Groundwater Flow, Contaminant Fate and Transport, and Distribution of Drinking Water Within the Service Areas of the Hadnot Point and Holcomb Boulevard Water Treatment Plants and Vicinities, U.S. Marine Corps Base Camp Lejeune, North Carolina-Chapter A: Summary and Findings, Agency for Toxic Substances and Disease Registry, Atlanta, GA, USA, March 2013. Available online: http://www.atsdr.cdc.gov/sites/lejeune/docs/chapter_A_hadnotpoint.pdf (accessed 29 July 2016).

30. Guan, J.; Anderson, B.A.; Aral, M.M.; Maslia, M.L. Theory, Development, and Application of Linear Control Model Methodology to Reconstruct Historical Contaminant Concentrations at Selected Water-Supply Wells-Supplement 5. In: Maslia, M.L.; Suárez-Soto, R.J.; Sautner, J.B.; Anderson, B.A.; Jones, L.E.; Faye, R.E.; Aral, M.M.; Guan, J.; Jang, W.; Telci, I.T.; Grayman, W.M.; Bove, F.J.; Ruckart, P.Z.; Moore, S.M. Analyses and Historical Reconstruction of Groundwater Flow, Contaminant Fate and Transport, and Distribution of Drinking Water Within the Service Areas of the Hadnot Point and Holcomb Boulevard Water Treatment Plants and Vicinities, U.S. Marine Corps Base Camp Lejeune, North CarolinaChapter A: Summary and Findings, Agency for Toxic Substances and Disease Registry, Atlanta, GA, USA, March 2013. Available online: http://www.atsdr.cdc.gov/sites/lejeune/docs/chapter_A_hadnotpoint.pdf (accessed 29 July 2016).

31. Jang, W.; Anderson, B.A.; Suárez-Soto, R.J.; Aral, M.M.; Maslia, M.L. Source Characterization and Simulation of the Migration of Light Nonaqueous Phase Liquids (LNAPLs) in the Vicinity of the Hadnot Point Industrial AreaSupplement 7. In: Maslia, M.L.; Suárez-Soto, R.J.; Sautner, J.B.; Anderson, B.A.; Jones, L.E.; Faye, R.E.; Aral, M.M.; Guan, J.; Jang, W.; Telci, I.T.; Grayman, W.M.; Bove, F.J.; Ruckart, P.Z.; Moore, S.M. Analyses and Historical Reconstruction of Groundwater Flow, Contaminant Fate and Transport, and Distribution of Drinking Water Within the Service Areas of the Hadnot Point and Holcomb Boulevard Water Treatment Plants and Vicinities, U.S. Marine Corps Base Camp Lejeune, North Carolina-Chapter A: Summary and Findings, Agency for Toxic Substances and Disease Registry, Atlanta, GA, USA, March 2013. Available online: http://www.atsdr.cdc.gov/sites/lejeune/docs/chapter_A_hadnotpoint.pdf (accessed 29 July 2016).

32. Faye, R.E. Analyses and Historical Reconstruction of Groundwater Flow, Contaminant Fate and Transport, and Distribution of Drinking Water Within the Service Areas of the Hadnot Point and Holcomb Boulevard Water Treatment Plants and Vicinities, U.S. Marine Corps Base Camp Lejeune, North Carolina-Chapter B: Geohydrologic Framework of the Brewster Boulevard and Castle Hayne Aquifer Systems and the Tarawa Terrace Aquifer. Agency for Toxic Substances and Disease Registry, Atlanta, GA, USA, March 2013. Available online: http://www.atsdr.cdc.gov/sites/lejeune/docs/chapter_B_hadnotpoint.pdf (accessed 29 July 2016).

33. Faye, R.E.; Jones, L.E.; Suárez-Soto, R.J. Descriptions and Characterizations of Water-Level Data and Groundwater Flow for the Brewster Boulevard and Castle Hayne Aquifer Systems and the Tarawa Terrace Aquifer-Supplement 3. In: Maslia, M.L.; Suárez-Soto, R.J.; Sautner, J.B.; Anderson, B.A.; Jones, L.E.; Faye, R.E.; Aral, M.M.; Guan, J.; Jang, W.; Telci, I.T.; Grayman, W.M.; Bove, F.J.; Ruckart, P.Z.; Moore, S.M. Analyses and Historical Reconstruction of Groundwater Flow, Contaminant Fate and Transport, and Distribution of Drinking Water Within the Service Areas of the Hadnot Point and Holcomb Boulevard Water Treatment Plants and Vicinities, U.S. Marine Corps Base Camp Lejeune, North CarolinaChapter A: Summary and Findings, Agency for Toxic Substances and Disease Registry, Atlanta, GA, USA, March 2013. Available online: http://www.atsdr.cdc.gov/sites/lejeune/docs/chapter_A_hadnotpoint.pdf (accessed 29 July 2016).

34. Harbaugh, A.W. MODFLOW-2005, The U.S. Geological Survey modular ground-water model-the Ground-Water Flow Processes, U.S. Geological Survey Techniques and Methods 6-A16, Reston, VA, USA, 2005.

35. Suárez-Soto, R.J.; Jones, L.E.; Maslia, M.L. Simulation of Three-Dimensional Groundwater Flow-Supplement 4. In: Maslia, M.L.; Suárez-Soto, R.J.; Sautner, J.B.; Anderson, B.A.; Jones, L.E.; Faye, R.E.; Aral, M.M.; Guan, J.; Jang, W.; Telci, I.T.; Grayman, W.M.; Bove, F.J.; Ruckart, P.Z.; Moore, S.M. Analyses and Historical Reconstruction of Groundwater Flow, Contaminant Fate and Transport, and Distribution of Drinking Water Within the Service Areas of the Hadnot Point and Holcomb Boulevard Water Treatment Plants and Vicinities, U.S. Marine Corps Base Camp Lejeune, North Carolina- 
Chapter A: Summary and Findings, Agency for Toxic Substances and Disease Registry, Atlanta, GA, USA, March 2013. Available online: http://www.atsdr.cdc.gov/sites/lejeune/docs/chapter_A_hadnotpoint.pdf (accessed 29 July 2016).

36. Jones, L.E.; Suárez-Soto, R.J.; Anderson, B.A.; Maslia, M.L. Characterization and Simulation of Fate and Transport of Selected Volatile Organic Compounds in the Vicinities of the Hadnot Point Industrial Area and Landfill-Supplement 6. In: Maslia, M.L.; Suárez-Soto, R.J.; Sautner, J.B.; Anderson, B.A.; Jones, L.E.; Faye, R.E.; Aral, M.M.; Guan, J.; Jang, W.; Telci, I.T.; Grayman, W.M.; Bove, F.J.; Ruckart, P.Z.; Moore, S.M. Analyses and Historical Reconstruction of Groundwater Flow, Contaminant Fate and Transport, and Distribution of Drinking Water Within the Service Areas of the Hadnot Point and Holcomb Boulevard Water Treatment Plants and Vicinities, U.S. Marine Corps Base Camp Lejeune, North CarolinaChapter A: Summary and Findings, Agency for Toxic Substances and Disease Registry, Atlanta, GA, USA, March 2013. Available online: http://www.atsdr.cdc.gov/sites/lejeune/docs/chapter_A_hadnotpoint.pdf (accessed 29 July 2016).

37. Zheng, C.; Wang, P.P. MT3DMS: A Modular Three-Dimensional Multi-Species Model for Simulation of Advection, Dispersion, and Chemical Reactions of Contaminants in Groundwater Systems: Documentation and User's Guide, Army Engineer Research and Development Center, Report No.: SERDP-99, Vicksburg, MS, USA, 1999. Available online: Available online: http://hydro.geo.ua.edu/mt3d/ (accessed 18 March 2015).

38. Zheng, C. MT3DMS v5.3 Supplemental User's Guide. Technical Report to the U.S. Army Engineer Research and Development Center, Department of Geological Sciences, University of Alabama, Tuscaloosa, AL, USA, 2010. Available online: http://hydro.geo.ua.edu/mt3d/mt3dms_v5_supplemental.pdf (accessed 18 March 2015).

39. Jang, W.; Aral, M.M. Density-Driven Transport of Volatile Organic Compounds and Its Impact on Contaminated Groundwater Plume Evolution. Transport in Porous Media. 2007, 67, 353-374.

40. Jang, W.; Aral, M.M. Effect of Biotransformation on Multi- Species Plume Evolution and Natural Attenuation. Transport in Porous Media. 2008, 72, 207-226.

41. Jang, W.; Aral, M.M. Analyses of Groundwater Flow, Contaminant Fate and Transport, and Distribution of Drinking Water at Tarawa Terrace and Vicinity, U.S. Marine Corps Base Camp Lejeune, North Carolina: Historical Reconstruction and Present-Day Conditions-Chapter G: Simulation of Three-Dimensional Multispecies, Multiphase Mass Transport of Tetrachloroethylene (PCE) and Associated Degradation By-Products, Agency for Toxic Substances and Disease Registry, Atlanta, GA, USA, April $2008 . \quad$ Available online: http://www.atsdr.cdc.gov/sites/lejeune/docs/ChapterG_TarawaTerrace.pdf (accessed 29 July 2016).

42. Masters, G.M. Introduction to Environmental Engineering and Science, $2^{\text {nd }}$ ed.; Prentice Hall: Upper Saddle, NJ, USA, 1998.

43. Saltelli, A.; Chan, K.; Scott, E.M.; Editors. Sensitivity Analysis. John Wiley \& Sons, Ltd: Chichester, England, 2000.

44. Ross, S.M. Introduction to Probability Models; Academic Press: San Diego, CA, USA, 1997.

45. Rossman, L.A. EPANET 2 User's Manual, U.S. Environmental Protection Agency, Report No.: EPA/600-R-00/057, National Risk Management Research Laboratory, Cincinnati, OH, USA, September 2000. Available online: https://www.epa.gov/water-research/epanet (accessed 29 July 2016).

46. Maslia, M.L.; Suárez-Soto, R.J.; Wang, J.; Aral, M.M.; Faye, R.E.; Sautner, J.B.; Valenzuela, C.; Grayman, W.M. Analyses of Groundwater Flow, Contaminant Fate and Transport, and Distribution of Drinking Water at Tarawa Terrace and Vicinity, U.S. Marine Corps Base Camp Lejeune, North Carolina: Historical Reconstruction and Present-Day Conditions-Chapter I: Parameter Sensitivity, Uncertainty, and Variability Associated with Model Simulations of Groundwater Flow, Contaminant Fate and Transport, and Distribution of Drinking Water, Agency for Toxic Substances and Disease Registry, Atlanta, GA, USA, February $2009 . \quad$ Available online: http://www.atsdr.cdc.gov/sites/lejeune/docs/ChapterI_TarawaTerrace.pdf (accessed 29 July 2016).

47. Sautner, J.B.; Maslia, M.L.; Valenzuela, C.; Grayman, W.M.; Aral, M.M.; Green. J.W. Jr. Field Testing of Water-Distribution Systems at the U.S. Marine Corps Base Camp Lejeune, North Carolina, in Support of an Epidemiologic Study. Proceedings of the World Environmental and Water Resources Congress, Anchorage, AK, USA, 2005 May 15-19; Walton, R.D., Ed.; American Society of Civil Engineers: Reston, VA, USA.

48. Sautner, J.B.; Maslia, M.L.; Grayman, W.M. Storage Tank Mixing Models: Comparison of Tracer Data with Model Simulation. Proceedings of the World Environmental and Water Resources Congress, Tampa, FL, USA, 2007 May 15-19; Kabbes, K.C., Ed.; American Society of Civil Engineers, Reston, VA, USA.

49. JTC Environmental Consultants, Inc. Laboratory Analyses on Naval Samples, JTC Report \#85-513, Contract No.: N6247084-B-6932, Rockville, MD, USA, November 27, 1985. 
50. ASTM. Standard Guide for Conducting a Sensitivity Analysis for a Ground-Water Flow Model Application, ASTM Guide D5611-94 (Reapproved 2002), ASTM International, West Conshohocken, PA, USA, October 1994.

51. Cullen, A.C.; Frey, H.C. Probabilistic Techniques in Exposure Assessment: A Handbook for Dealing with Variability and Uncertainty in Models and Inputs; Plenum Press: New York, USA, 1999.

52. Tung, Y-K.; Yen B-C. Hydrosystems Engineering Uncertainty Analysis, McGraw-Hill: New York, NY, USA, 2005.

53. Hill, M.C.; Tiedeman, C.R. Effective Groundwater Model Calibration. John Wiley \& Sons, Inc.: Hoboken, NJ, USA, 2007.

(C) 2016 by the authors; licensee Preprints, Basel, Switzerland. This article is an open access article distributed under the terms and conditions of the Creative Commons by Attribution (CC-BY) license (http://creativecommons.org/licenses/by/4.0/). 